\title{
Severe Congenital Neutropenia Due To G6PC3 Deficiency Case Series of Five Patients and Literature Review
}

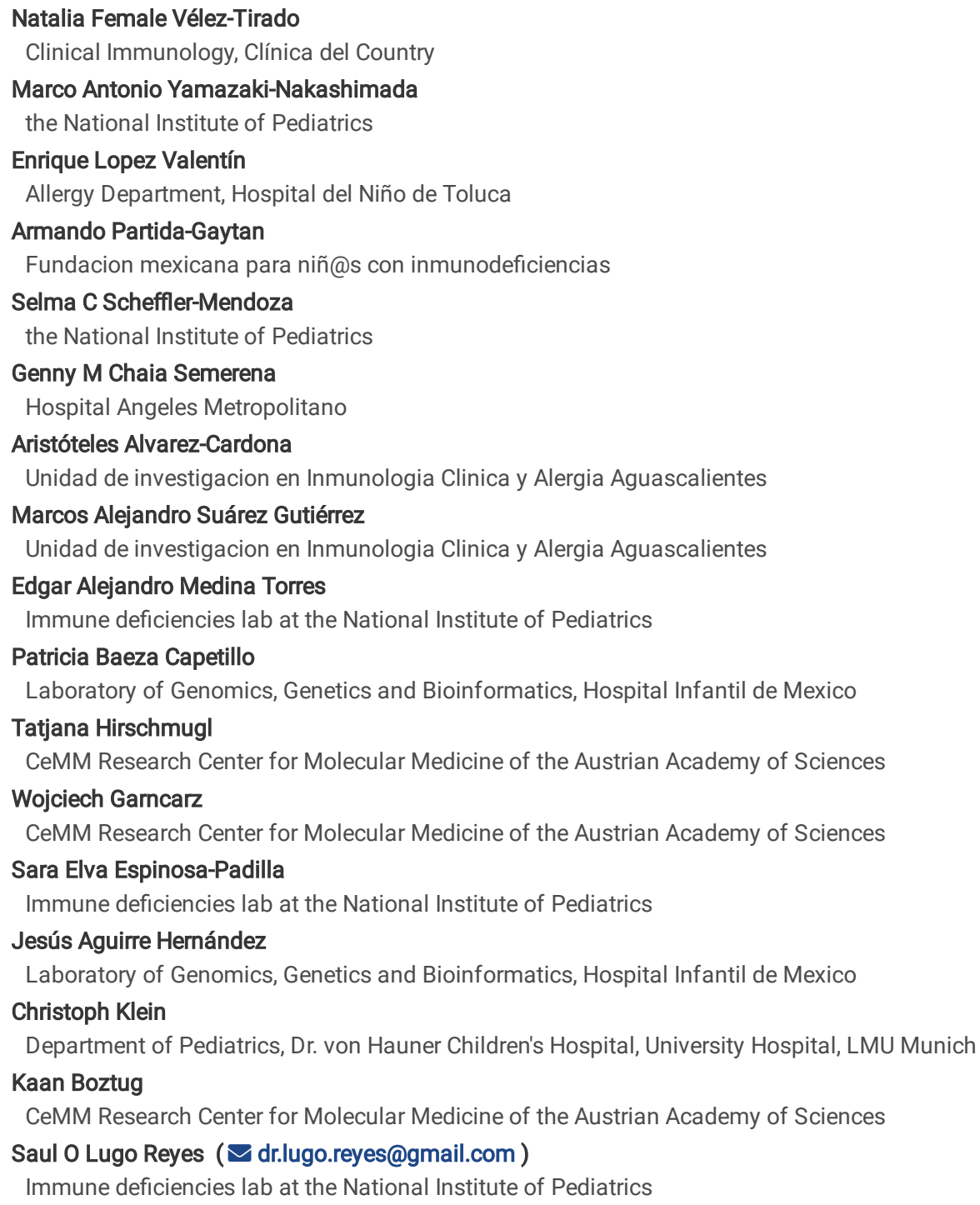

\section{Research Article}

Keywords: G6PC3, neutropenia, syndromic, severe congenital neutropenia type 4, Dursun Syndrome, clinical features, genetic variants, literature review, case series.

Posted Date: July 7th, 2021

DOI: https://doi.org/10.21203/rs.3.rs-356870/v2

License: (c) (i) This work is licensed under a Creative Commons Attribution 4.0 International License. Read Full License

Version of Record: A version of this preprint was published at Scandinavian Journal of Immunology on December 29th, 2021. See the published version at https://doi.org/10.1111/sji.13136. 


\section{Abstract}

Glucose-6-phosphate catalytic subunit 3 (G6PC3) deficiency is characterized by severe congenital neutropenia with recurrent pyogenic infections, a prominent superficial venous pattern, and cardiovascular and urogenital malformations, caused by an alteration of glucose homeostasis, with increased endoplasmic reticulum stress and cell apoptosis. We describe five new cases from Mexico, and review 89 more patients reported in the past decade, to delineate the most frequent laboratory and genetic features, their treatment, and outcomes, and to expand the knowledge of syndromic and non-syndromic phenotypes in these patients.

\section{Introduction}

While rare diseases are individually infrequent, collectively they afflict around ten percent of the world population. Patients with rare diseases typically must endure a "diagnostic odyssey" that may take several years, before receiving a correct diagnosis and treatment. Inborn errors of immunity (IEI) are a group of rare congenital diseases caused by monogenic germline variants that result in the modification of protein expression or function, affecting the development, function, and homeostasis of the immune system (1). IEl comprise a wide spectrum of disorders that may manifest not only with increased susceptibility to infections, but also with inflammation, autoimmunity, allergy, or malignancy.

In 1950, Rolf Kostmann first described "hereditary agranulocytosis", or severe congenital neutropenia (SCN), characterized by an early onset of recurrent bacterial and fungal infections of the mouth, umbilical stump, skin, gastrointestinal tract, bones, lungs, and lymph nodes (2).

Although pathogenic variants in ELANE are the most common genetic etiology of autosomal dominant (AD) SCN, several others have been described in the last two decades: X-linked WAS gain-of-function (GOF), autosomal recessive (AR) HAX1, GFI1, CSF3R, and G6PC3 loss of function (LOF); and AD TCIRG1 haploinsufficiency. The molecular cause is unknown in about $30 \%$ of patients with SCN.

In 2009, Boztug and Klein reported (3) a series of 12 patients with congenital neutropenia and various cardiovascular and urogenital developmental anomalies, who had homozygous and compound heterozygous variants in the gene encoding glucose-6-phosphatase catalytic subunit 3 (G6PC3 deficiency, also known as type 4 SCN, OMIM \#612541), as well as prominent superficial veins (mainly in trunk and limbs). G6PC3 is located on chromosome 17q21 and spans 6 exons.

Independently, a pair of Turkish siblings were reported with pulmonary arterial hypertension, and other abnormalities including cardiac, hematological, and skeletal defects (4). Over the last decade, the spectrum of the disease has continuously widened to include non-syndromic forms and new features (5). Here, we describe five patients from Mexico, and review the available literature for clinical features, genetic variants, treatment, and outcome of 89 more patients with G6PC3 deficiency.

\section{Case Reports}

\section{Patient 1}

A 3-month-old male, born to non-consanguineous parents from rural central Mexico, was born prematurely at 35 weeks and admitted to the neonatal intensive care unit for extensive edema and ecchymoses, with respiratory distress that required mechanical ventilation. He was started on intravenous antibiotics for pneumonia and sepsis.

Physical examination found low weight, a low-grade systolic murmur, hepatomegaly, and cryptorchidism; prominent superficial veins in thorax, abdomen and all four limbs were later noted. Laboratory work-up reported transient-variable anemia, lymphopenia, and thrombocytopenia; as well as severe persistent neutropenia and pan-hypogammaglobulinemia. An echocardiogram showed a persistent foramen ovale (4mm) with bidirectional shunt and pulmonary arterial hypertension at $58 \mathrm{mmHg}$. Abdominal ultrasound revealed pyloric stenosis and severe bilateral hydronephrosis.

Filgrastim (granulocyte-colony stimulating factor, G-CSF) was started at $3-5 \mu \mathrm{g} / \mathrm{kg} / \mathrm{d}$, with a spectacular but transient increase in neutrophil count, as well as prophylactic antibiotics (trimethoprim/sulfamethoxazole, itraconazole) and monthly intravenous immunoglobulin (IVIG) at $1 \mathrm{~g} / \mathrm{kg}$. A homozygous singlenucleotide deletion in exon 1 of G6PC3 (c.210delC, p.Phe71SerfsTer46), was identified through Sanger sequencing, a variant previously reported (6). In time, the dosage of filgrastim had to be increased up to $22 \mathrm{mg} / \mathrm{kg} / \mathrm{d}$, to achieve an acceptable neutrophil count. Due to this severe and early presentation, hematopoietic stem-cell transplantation (HSCT) was performed in this patient at the age of 15 months. Unfortunately, he developed neutropenic colitis and died of sepsis on day +29 .

\section{Patient 2}

A 15-year-old female, born to non-consanguineous parents from a small rural community (300 inhabitants), was admitted for a 6-year history of episodic diarrhea and intense-generalized abdominal pain, each episode lasting between 7 and 14 days, for which she had received multiple antibiotic treatments with slight improvement. Her past medical history also included pneumonia at 4 months old, as well as recurrent otitis media and other upper airway infections.

On admission, we found a severely undernourished patient, with prominent superficial veins, finger clubbing, brachymetatarsia of the third toes, and bilateral sensorineural hearing loss. Laboratory workup revealed anemia, intermittent neutropenia, and lymphopenia. Colonoscopy and histopathology were compatible with Crohn's disease; echocardiography revealed mild tricuspid insufficiency.

She started treatment with mesalazine, trimethoprim-sulfamethoxazole (TMP-SMZ), prednisone, IVIG every 21 days, and filgrastim (G-CSF, 10mcg/kg/d). Through Sanger sequencing, a homozygous single-nucleotide deletion was found in exon 1 of G6PC3 (c.210delC, p.Phe71SerfsTer46), the same variant 
identified in Patient 1.

At age 16, she developed bronchopulmonary aspergillosis and was treated with voriconazole. Despite good adherence, complete remission of IBD was never achieved. At 17, she presented with acute abdominal pain, fever, and vomit; she died with abdominal sepsis after intestinal perforation. Remarkably, prior to this catastrophic event, she had been asymptomatic. The autopsy revealed severe extensive bowel inflammation, which was at odds with her clinical symptoms and signs.

\section{Patient 3}

A 3-month-old female patient, born to non-consanguineous Mexican parents, with a family history of three paternal uncles who died before the age of 5 years. She first presented with neonatal sepsis requiring intravenous antibiotics, after which she had 5 episodes of pneumonia and a surgically corrected rectovaginal fistula.

On physical examination, we found severe chronic malnutrition, prominent superficial veins in her abdominal wall, bilateral sensorineural hearing loss, and supplemental oxygen dependence. Her clinical assessment revealed severe neutropenia, atrial septal defect, and severe pulmonary damage due to multiple atelectasis and bronchiectasis, associated with pulmonary arterial hypertension. Whole-exome sequencing identified the same homozygous single-nucleotide deletion in G6PC3 (c.210delC; p.Phe71SerfsTer46) as in patients 1 through 4. Patient 3 is currently 3 years old, alive, and well, under treatment with granulocyte colony stimulating factor (G-CSF, filgrastim) $30 \mathrm{mcg} / \mathrm{kg} / \mathrm{day}$.

\section{Patient 4}

A 9-year-old boy from northern Mexico, with no known consanguinity or family history of infections or early deaths. He started at age 3 months with suppurative otitis media and pneumonia that required admission to the intensive care unit (ICU) and was hospitalized for a month. Neutropenia was recorded since then, with absolute neutrophil counts (ANC) within the range of 450 to 790/mm3, which responded well to filgrastim (G-CSF).

However, despite the increase in neutrophil numbers, the patient persisted with multiple respiratory tract infections requiring frequent hospitalizations and parenteral antibiotics up to 5 years of age. He also presented with oral, finger and perianal abscesses, without any isolates. From 6 years on, the frequency of infections decreased to 1-2 per year. On physical examination, weight and height were normal; he had a prominent superficial venous pattern in trunk and limbs, as well as redundant skin folds in the neck, and a left inguinal hernia.

Laboratory workup reported intermittent thrombocytopenia and persistent lymphopenia; bone marrow aspirate showed myeloid cell hypoplasia and nonspecific findings. An echocardiogram revealed persistent foramen ovale (corrected percutaneously with an Amplatzer device), and pulmonary hypertension of $45 \mathrm{~mm} / \mathrm{Hg}$, whereas a Doppler ultrasound of the liver documented compensated portal hypertension. Percutaneous liver biopsy reported sinusoid fibrosis and steatosis.

Sanger sequencing identified a compound heterozygous genotype, with variants in exons 1 and 4 of G6PC3: the same single-nucleotide deletion (c.210delC, p.Phe71SerfsTer46), and a nonsense transition (c.481C > T, p.Arg161*), respectively. The patient is currently alive and well, under treatment with granulocyte colony stimulating factor (G-CSF)

\section{Patient 5}

A 2-year-old female, born to non-consanguineous Mexican parents, was referred to our care for a history of cow's milk allergy, allergic asthma and rhinitis, recurrent otitis media, sepsis, urinary tract infection, autoimmune colitis and disseminated herpes zoster.

On physical examination, she did not have any syndromic features. Complete blood count reported severe neutropenia, anemia, intermittent lymphopenia, and thrombocytopenia. Through whole-exome sequencing analysis, a compound heterozygous genotype consisting of two single-nucleotide deletions in exons 1 and 4 of G6PC3, was identified (c.210delC, p.lle70HisfsTer46); c.421del, p.Trp141GlyfsTer2); this second frameshift variant has not been previously described and is not found in gnomAD. The patient is alive under treatment with filgrastim (G-CSF) and prophylaxis with TMP-SMZ and fluconazole.

\section{Ethics approval}

This case series study was granted exemption by the National Institute of Pediatrics Research and Ethics Committee due to its retrospective design. All authors subscribe the 1964 Declaration of Helsinki by the World Medical Organization and its later amendments regarding human experimentation. All patients or their guardians consented to genetic diagnostic research and publication.

\section{Review of the literature}

We searched the PubMed/Medline database for the terms ("G6PC3 deficiency" OR "Dursun syndrome" OR "Severe congenital neutropenia type 4"), and selected articles published in English from 2009 to 2020. We found 89 patients reported from at least 14 countries in 4 continents (See tables. Not all reports included the country of origin). Table 1 describes their origins, demographic, clinical and laboratory features, treatment, and outcome. Table 2 collects their genetic variants. In Table 3, we summarize the most common features and findings.

Ninety-four patients were included in this review (whenever the denominator is less than 94 , that attribute was not available for some patients). The distribution of the disease was similar between males (52/92,56\%) and females. Most cases were from Middle East countries (47.8\%). None of the patients had adverse reactions to live vaccines such as BCG. All patients presented at least one severe infection prior to 2 years of age; however, only $28.5 \%$ (26/91) were diagnosed before the age of two. 
Syndromic features were identified in 71/94 (75.5\%) of the patients. The most frequent alterations were cardiovascular defects, mainly atrial septal defect in $52 / 94$ (55.3\%), valve disease 21/94 (22.3\%), patent ductus arteriosus 10/94 (10.6\%); and prominent superficial veins 58/94 (61.7\%). Some of the cardiovascular malformations resulted in pulmonary hypertension secondary to pulmonary overflow. However, a group of patients had primary pulmonary hypertension not related to congenital cardiopathy. Thirty-seven patients (39.3\%) presented with urological or genital malformations, which were more commonly seen in male patients, being cryptorchidism the most prevalent among those: $21 / 52$ (40.53\%). Other reported anomalies were urachal fistula, unilateral or bilateral inguinal hernia, hydronephrosis, genital dysplasia, and micropenis. Endocrine abnormalities were described in $28 / 94$ patients (30\%), with variable manifestations ranging from growth retardation in 12/94 (12.7\%), to puberal delay (in 6/94, 6.3\%), and growth hormone deficiency (4/94, $4.3 \%$ ).

Other non-hematological features were sensorineural hearing loss in 12/94 (12.7\%), developmental delay (11/94, 12\%), and microcephaly (5/94, 5.3\%). Inflammatory bowel disease was present in 10/94 (10.6\%) of patients, with a higher prevalence in the syndromic group (70\%); two of these patients also had oculocutaneous albinism, three had persistent lymphopenia, and one T cell lymphopenia, suggesting a more severe compromise. Splenomegaly was reported in $6 / 94(6.3 \%)$.

Immunological analysis was not performed homogeneously in all patients; flow cytometry, immunoglobulins or lymphoproliferation were available only for 21/94. Although they all had severe neutropenia, some showed an intermittent increase in neutrophil counts. Intermittent thrombocytopenia was reported in $37 / 94$ patients (39.3\%), and 17 of 94 (18\%) had lymphocyte counts below $1500 / \mu l$. Nineteen patients had their serum immunoglobulin levels measured, of which 9 (47.3\%) presented with hypergammaglobulinemia and 2 hypogammaglobulinemia (10.5\%).

Treatment was described in 76 patients; one patient did not require any pharmacological intervention, while $63 / 76$ (82.8\%) were given G-CSF, 2.6\% received pegfilgrastim, and $3.9 \%$ received prophylactic co-trimoxazole as only treatment; IVIG was administered in $5 / 76$ (6.5\%) patients. Only 3 patients (4\%) received hematopoietic stem cell transplant (HSCT). Patient 69 underwent HSCT due to severe IBD refractory to medical treatment and showed complete resolution of gastrointestinal symptoms; whereas patient 70 was transplanted because of the severe presentation of the disease and died from complications associated with the procedure. Long-term outcome was available for 79 patients, with survival at the time of publication of the original papers of $67 / 79$ (84.8\%) (Table 1).

Among the 94 reported patients, homozygous missense was the most frequent variant type (Table 2). Homozygous frameshift insertions, deletions, splice-site, or nonsense were also reported. Although the transition c. $130 \mathrm{C}>\mathrm{T}$ was associated with non-syndromic neutropenia in Pakistani patients, a genotypephenotype correlation has not been confirmed.

\section{Discussion}

Including our five patients, a little over 100 G6PC3 deficiency cases have been described in the literature. They frequently present with recurrent and severe bacterial infections during the first year of life, such as otitis media, skin abscesses, urinary tract infections, sino-pulmonary infections, and sepsis. The diagnosis is suspected based on microbes (bacterial and fungal), infection sites (mouth, skin, bone, blood, lymph nodes, umbilical stump, respiratory and gastrointestinal tracts), and hematological findings: severe neutropenia was found in all reported patients; thirty-seven patients had intermittent thrombocytopenia without clinical bleeding. Bone marrow aspirates of patients with G6PC3 deficiency showed a great diversity of findings, including: normocellular or hypercellular bone marrow, maturation arrest, and even myelokathexis (7). So far, there is no evidence that G6PC3 deficiency is a preleukemic condition. In this review, we found only one case of leukemia (P70) (8); no other reports of malignant transformation, as has been described in other SCN syndromes (5) (9).

We have been able to include here most of the patients reported in the medical literature, expanding the phenotype, and describing the typical hematological and non-hematological features of G6PC3 deficient patients. The main limitations are the descriptive retrospective nature of the study, the fact that the information we rely upon is provided by different sources and authors, and lastly, the possibility of important data being lost throughout. Additionally, this is not a systematic review, and we are only including cases reported in English.

The activity of glucose-6-phosphatase is regulated by 3 genes: G6PC1, expressed in liver, small intestine and kidney, is related to the glycogenolytic and gluconeogenic pathways. G6PC2, expressed only in the pancreatic cells, is related to glucose level control; and G6PC3, ubiquitously expressed, hydrolyzes glucose-6-phosphate to glucose in the final step of gluconeogenesis and glycogenolysis (10) in the endoplasmic reticulum. G6PC3 is essential to control neutrophil viability (3); its loss of function is associated with neutropenia due to an increase of endoplasmic reticulum stress and abnormal glucose homeostasis that leads to an increased susceptibility to apoptosis of neutrophils, skin fibroblasts and myeloid cells (11)(12). The above findings suggest that G6PC3 deficiency is a quantitative and qualitative neutrophil disease (13).

The immunological features are diverse and include T cell lymphopenia, thymic hypoplasia, and dysgammaglobulinemia. Some articles suggest that the $T$ cell lymphopenia found in patients with G6PC3 deficiency may be associated with thymic hypoplasia. Nevertheless, the mechanisms leading to this thymic alteration are unclear (14). Some G6PC3-deficient patients may have a more profound immunological defect, and might require a deeper approach, including $\mathrm{T}$ cell flow cytometry and lymphoproliferation assays. When abnormalities in the function of $\mathrm{T}$ and $\mathrm{B}$ cells are demonstrated, it is mandatory to consider immunoglobulin replacement (9). Progressive lymphopenia has also been reported; therefore, immunological long-term follow-up is required.

Non-hematological features are pivotal in differentiating G6PC3 deficiency from other causes of SCN: structural heart defects, prominent superficial veins, urogenital malformations, growth retardation, pubertal and developmental delay (15). The phenotypic spectrum of the disease is expanding, as it might be syndromic or non-syndromic, the latter group being harder to diagnose given the absence of non-hematological features. (16). In this review, 23/94 (24.4\%) of the patients did not have any syndromic association. Thus, G6PC3 deficiency should be considered in any SCN of unknown etiology. 
The most frequent non-hematological features are cardiovascular malformations (17), atrial septal defect being the most common among those (55.3\%). A wide range of cardiac abnormalities has been described in the literature, including heart valve abnormalities (mitral insufficiency, pulmonary valve stenosis, mitral and tricuspid insufficiency), followed by patent ductus arteriosus, coronary aneurysm, hypoplastic left ventricle and foramen ovale. The prominent superficial venous pattern was present in 58/94 (61.7\%) of the patients reported, making it a frequent non-hematological feature. This alteration is less evident in childhood but becomes more prominent with age. These vascular changes have been attributed to increased cell apoptosis, and they can develop into varicose veins and ulcers during adulthood (11).

IBD has been reported in 10/94 reported patients with G6PC3 deficiency. Some authors suggest that autoinflammation through inflammasome activation may aggravate the IBD activity in G6PC3 deficiency (12). IBD is a common finding in phagocyte defects, such as chronic granulomatous disease and leukocyte adhesion deficiency; these patients show dysregulated and poorly controlled inflammation perpetuated by a breakdown in the mucosal homeostasis and defective bacterial recognition and clearance (18) (19) (20) (21). Fecal calprotectin is not a good marker of inflammation in these patients since the neutropenia may give false-negative results; stool a1 antitrypsin may be a more reliable marker (22). Hematopoietic stem cell transplant is a reasonable alternative for severe gastrointestinal manifestations resistant to conventional treatments (17).

The treatment most frequently used was filgrastim (G-CSF), leading to an increase in the number of neutrophils, together with an improvement in the patient's quality of life due to a decrease in the infection rate. In a murine G6PC3 ${ }^{-/-}$model, G-CSF delayed, but did not prevent, neutrophil apoptosis. In that study, a fiveday G-CSF treatment regime corrected neutropenia, stimulated glucose uptake and improved neutrophil function (23). Depending on the severity of the defect, some patients received prophylactic antibiotics; mild phenotypes were treated with co-trimoxazole alone. On the other hand, more severe phenotypes may require G-CSF, antibiotics and gammaglobulin replacement. In general, the reported survival is high, with a good quality of life as long as patients use filgrastim (G-CSF) and their malformations are surgically corrected. In recent years, therapeutic options other than G-CSF have emerged, such as SGLT2 inhibitor empagliflozin, a drug that decreases the concentration of 1,5-anhydroglucitol-6-phosphate (1,5AG6P) a toxic metabolite that accumulates in the plasma of G6PC3 patients (24); empagliflozin reduces the concentration of toxic metabolites allowing a recovery in neutrophil function (25). This novel treatment appears promising, although further studies are needed. So far, there is no recommendation to endorse or promote HSCT as a definitive treatment for the neutropenia. In this review, only 3 patients underwent HSCT, of which one died due to complications associated with the procedure.

We recommend the use of filgrastim (G-CSF), as it is considered safe and improves neutrophil counts, prevents the recurrence of infections, and it subjectively improved the quality of life in all reported cases. The dose and frequency of administration vary with the needs of each patient. We also recommend the use of oral ambulatory prophylactic antibiotics; co-trimoxazole is a cheap and safe choice to diminish the rate and severity of infections, particularly in countries where the access to G-CSF is limited. A small group of patients has a higher immune compromise, so we suggest that all patients who either continue to suffer recurrent infections despite having normal levels of neutrophils or who have persistent lymphopenia, should be further evaluated with immunoglobulin levels testing, flow cytometry and lymphoproliferation assays. So far, HSCT is only suggested in patients with IBD refractory to conventional pharmacological treatment, and is not routinely recommended, with most reports showing a good evolution with the exclusive use of filgrastim (G-CSF) and surgery to treat malformations.

Although G6PC3 deficiency is a rare disease, there is an increasing number of case reports around the world. This allows us to have a clearer idea of the clinical picture, the associated syndromic features, and the best treatment for these patients. Given a clinical suspicion of G6PC3, it is appropriate to carry out a complete medical history that includes consanguinity, type and number of infections, and microbiological isolates. An exhaustive physical examination is mandatory, searching for a triangular face, depressed nasal bridge, redundant neck skin, cutis laxa, prominent veins, cardiac murmur, overlapping toes and urogenital malformations, as they may be present in the syndromic phenotype.

All patients with suspected G6PC3 deficiency should have an echocardiogram and renal ultrasound. They must also have a close monitoring of weight, height, and growth velocity, with any alteration prompting measurements of growth hormone levels and an evaluation by an endocrinologist. Although it is an infrequent manifestation, the presence of loose stools or bloody diarrhea, tenesmus, or abdominal pain, suggests IBD. These patients should be evaluated with a complete blood count, erythrocyte sedimentation rate or C-reactive protein, albumin, fecal calprotectin, and upper endoscopy/colonoscopy with biopsies.

The c.210delC variant was present in all 5 Mexican patients from this report, and in most Hispanic patients reported to date. Banka and Newman (17) pointed out there might be some founder effects: Arg253His is frequent in the Middle East, Gly260Arg is more frequent in Caucasians from Europe, and Phe71SerfsTer46 (c.210delC) is common among unrelated individuals of Hispanic descent. With a frequency of 0.00011 in gnomAD (gnomad.broadinstitute.org/variant/17-42148542-TC-T?dataset = gnomad_r2_1), all 28 existing alleles (16 women and 12 men, all heterozygous) are from Latino/Admixed American individuals. Our 5 patients came from different regions of the country, mostly from Central and North Mexico. Although there was no known history of consanguinity, endogamy at small, geographically isolated communities, might explain the homozygosity in three of the families.

There are multiple unanswered questions about G6PC3-deficient patients. The cause for the heterogeneity of the bone marrow findings is currently unknown, as is the reason why some patients present with thymic hypoplasia, lymphopenia and hypogammaglobulinemia. Whether the neurodevelopmental delay and hearing loss described in some patients, are caused by prolonged hospitalizations and recurrent infections, or they are part of the disease phenotype, is also unclear. Other exceptional clinical features, such as oculocutaneous albinism, might result from different autosomal recessive gene defects in highly consanguineous populations.

In conclusion, we described 5 and reviewed 89 more cases of G6PC3 deficiency reported in the literature during the last 10 years, including clinical features, treatment, prognosis, and mutational analysis. It is a disease with a high heterogeneity, with syndromic and non-syndromic phenotypes. A possible G6PC3 deficiency should be considered in every patient with severe congenital neutropenia. The follow-up should include growth and development evaluation, as well as an assessment of complete blood count, echocardiogram, and renal ultrasound, while individualizing the needs of each patient, as clinical penetrance is

Page 5/25 
variable, and no genotype-phenotype has been described. The ongoing management of the disease should be conducted within a multidisciplinary team. We recommend treating with G-CSF and antibiotic prophylaxis, as they seem to improve the frequency of infections and quality of life. An increasing number of cases of G6PC3 deficiency in the world is likely to continue to be identified due to easier access to diagnostic methods, expanding our understanding of this disease.

\section{List Of Abbreviations}

GOF, gain of function; Severe congenital neutropenia (SCN), glucose-6-phosphate catalytic subunit 3 (G6PC3), inflammatory bowel disease (IBD), atrial septal defect (ASD), pulmonary hypertension (PH), granulocyte colony stimulating factor (G-CSF).

\section{Declarations}

\section{ACKNOWLEDGMENTS}

We thank the patients and their families for their trust and patience. The Mexican Foundation for children with immune deficiencies (Fumeni, AC) covered the costs of the shipment of clinical samples from patients with suspected G6PC3 deficiency.

\section{FUNDING}

The authors received no financial support for the research, authorship, and/or publication of this article.

\section{DISCLOSURE OF CONFLICTS OF INTEREST}

APG works as medical manager at Glaxo-Smith Kline. GMCS used to be a medical advisor for Astra Zeneca. None related to this study.

\section{AVAILABILITY OF DATA AND MATERIAL}

The authors confirm that the data supporting the findings in this study are available within the article and in supplementary materials.

\section{CODE AVAILABILITY}

Not applicable

\section{AUTHORSHIP CONTRIBUTIONS}

Substantial contribution to the acquisition of the data was provided by N Velez-Tirado, MA Yamazaki-Nakashimada, E Lopez Valentín, A Partida-Gaytan, SC Scheffler-Mendoza, GM Chaia Semerena, A Alvarez-Cardona, and MA Suárez Gutiérrez, who also suspected the diagnosis and cared for the patients. Substantial contributions to the conception of the work, analysis of the data and drafting of the manuscript were provided by N Velez-Tirado, MA Yamazaki Nakashimada, and SO. Lugo Reyes. Substantial contribution to laboratory and genetic diagnoses were provided by EA Medina-Torres, P Baeza-Capetillo, T Hirschmugl, W Garncarz, SE Espinosa-Padilla, J Aguirre Hernández, C Klein, and K Boztug, who also revised the manuscript critically. All authors read and approved the final manuscript.

\section{ETHICS APPROVAL}

This case series study was granted exemption by the National Institute of Pediatrics Research and Ethics Committee due to its retrospective design. All authors subscribe the 1964 Declaration of Helsinki by the World Medical Organization and its later amendments regarding human experimentation.

\section{CONSENT TO PARTICIPATE}

Informed consent was obtained from all individual participants included in the study.

\section{CONSENT TO PUBLISH}

The participant has consented to the submission of the case report to the journal

\section{References}

1. Sullivan KE, Stiehm ER, editors. Stiehm's Immune Deficiencies [Internet]. 2nd ed. Sullivan KE, Stiehm R, editors. Stiehm's Immune Deficiencies. New York: Elsevier; 2020 [cited 2021 Feb 17]. 1332 p. Available from: https://www.elsevier.com/books/stiehms-immune-deficiencies/sullivan/978-0-12-816768-7.

2. Klein C. Kostmann's, Disease and HCLS1-Associated Protein X-1 (HAX1) [Internet]. Vol. 37, Journal of Clinical Immunology. Springer New York LLC; 2017 [cited 2021 Feb 19]. p. 117-22. Available from: https://link.springer.com/article/10.1007/s10875-016-0358-2.

3. Boztug K, Appaswamy G, Sc M, Ashikov A, Ph D, Alejandro A, et al. A novel syndrome with congenital neutropenia caused by mutations in G6PC3. N Engl J Med. 2009;360(1):32-43.

4. Dursun A, Ozgul RK, Soydas A, Tugrul T, Gurgey A, Celiker A, et al. Familial pulmonary arterial hypertension, leucopenia, and atrial septal defect: a probable new familial syndrome with multisystem involvement. Clin Dysmorphol [Internet]. 2009 Jan [cited 2021 Feb 22];18(1):19-23. Available from: https://journals.Iww.com/00019605-200901000-00004. 
5. Boztug K, Rosenberg PS, Dorda M, Banka S, Moulton T, Curtin J, et al. Extended spectrum of human glucose-6-phosphatase catalytic subunit 3 deficiency: Novel genotypes and phenotypic variability in severe congenital neutropenia. J Pediatr. 2012;160(4).

6. Xia J, Bolyard AA, Rodger E, Stein S, Aprikyan AA, Dale DC, et al. Prevalence of mutations in ELANE, GFI1, HAX1, SBDS, WAS and G6PC3 in patients with severe congenital neutropenia. Br J Haematol [Internet]. 2009 Nov [cited 2021 Feb 17];147(4):535-42. Available from: /pmc/articles/PMC2783282/.

7. Banka S, Wynn R, Newman WG. Variability of bone marrow morphology in G6PC3 mutations: Is there a genotype-phenotype correlation or age-dependent relationship? Am J Hematol. 2011 Feb;86(2):235-7.

8. Desplantes C, Fremond ML, Beaupain B, Harousseau JL, Buzyn A, Pellier I, et al. Clinical spectrum and long-term follow-up of 14 cases with G6PC3 mutations from the French severe congenital neutropenia registry. Orphanet J Rare Dis. 2014;9(1):1-15.

9. Kiykim A, Baris S, Karakoc-Aydiner E, Ozen AO, Ogulur I, Bozkurt S, et al. G6PC3 Deficiency. J Pediatr Hematol Oncol. 2015 Nov;37(8):616-22.

10. Aytekin C, Germeshausen M, Tuygun N, Dogu F, Ikinciogullari A. A novel G6PC3 gene mutation in a patient with severe congenital neutropenia. J Pediatr Hematol Oncol. 2013;35(2):2012-4.

11. Banka S, Chervinsky E, Newman WG, Crow YJ, Yeganeh S, Yacobovich J, et al. Further delineation of the phenotype of severe congenital neutropenia type 4 due to mutations in G6PC3. Eur J Hum Genet. 2011;19(1):18-22.

12. Bolton C, Burch N, Morgan J, Harrison B, Pandey S, Pagnamenta AT, et al. Remission of Inflammatory Bowel Disease in Glucose-6-Phosphatase 3 Deficiency by Allogeneic Haematopoietic Stem Cell Transplantation. J Crohn's Colitis. 2019;1-6.

13. Boztug K, Klein C. Genetics and Pathophysiology of Severe Congenital Neutropenia Syndromes Unrelated to Neutrophil Elastase. Hematol Oncol Clin North Am. 2013 Feb;27(1):43-60.

14. Bégin P, Patey N, Mueller P, Rasquin A, Sirard A, Klein C, et al. Inflammatory bowel disease and T cell lymphopenia in G6PC3 deficiency. J Clin Immunol. 2013;33(3):520-5.

15. Eghbali A, Eshghi P, Malek F, Rezaei N. Cardiac and renal malformations in a patient with sepsis and severe congenital neutropenia. Iran J Pediatr. 2010;20(2):225-8.

16. Banka S, Wynn R, Byers H, Arkwright PD, Newman WG. G6PC3 mutations cause non-syndromic severe congenital neutropenia. Mol Genet Metab. 2013;108(2):138-41.

17. Banka S, Newman WG. A clinical and molecular review of ubiquitous glucose-6-phosphatase deficiency caused by G6PC3 mutations. Orphanet J Rare Dis. 2013;8(1).

18. Chiriaco M, Salfa I, Di Matteo G, Rossi P, Finocchi A. Chronic granulomatous disease: Clinical, molecular, and therapeutic aspects. Pediatr Allergy Immunol. 2016;27(3):242-53.

19. Mistry A, Scambler T, Parry D, Wood M, Barcenas-Morales G, Carter C, et al. Glucose-6-phosphatase catalytic subunit 3 (G6PC3) deficiency associated with autoinflammatory complications. Front Immunol. 2017;8(NOV):1-7.

20. Kelsen JR, Sullivan KE, Rabizadeh S, Singh N, Snapper S, Elkadri A, et al. NASPGHAN Position Paper on The Evaluation and Management for Patients with Very Early-Onset Inflammatory Bowel Disease (VEO-IBD). Intergovernmental Panel on Climate Change, editor. J Pediatr Gastroenterol Nutr. 2019 Dec;53(9):1.

21. Goenka A, Doherty JA, Al-Farsi T, Jagger C, Banka S, Cheesman E, et al. Neutrophil dysfunction triggers inflammatory bowel disease in G6PC3 deficiency. J Leukoc Biol. 2020;(August):1-8.

22. Kaya Z, Eğritaş Ö, Albayrak M, Göçün PU, Koçak Ü, Dalgiç B, et al. Resolution of inflammatory colitis with pegfilgrastim treatment in a case of severe congenital neutropenia due to glucose 6 phosphatase catalytic subunit-3 deficiency. J Pediatr Hematol Oncol. 2014;36(5):316-8.

23. Sik Jun H, Mok Lee Y, Duk Song K, Mansfield BC, Chou JY. G-CSF improves murine G6PC3-deficient neutrophil function by modulating. Blood. 2011;117(14):3881-92.

24. Veiga-da-Cunha M, Chevalier N, Stephenne X, Defour JP, Paczia N, Ferster A, et al. Failure to eliminate a phosphorylated glucose analog leads to neutropenia in patients with G6PT and G6PC3 deficiency. Proceedings of the National Academy of Sciences. 2019;116(4)1241-1250.

25. Wortmann S, Van Hove J, Derks T, Chavalier N, Knight V, Koller A, et al. Traeting neutropenia and neutrophil dysfunction in glycogen storage disease type Ib with an SGLT2 inhibitor. Blood. 2020;136(9):1033-43.

\section{Tables}

Table 1. Demographic, clinical and laboratory features of 94 patients with G6PC3 deficiency 


\begin{tabular}{|c|c|c|c|c|c|c|c|c|}
\hline Author & Individual & Country & $\begin{array}{l}\text { Age } \\
\text { (years) }^{\mathrm{a}}\end{array}$ & $\operatorname{Sex}^{b}$ & Clinical remarks & Cytopenias & Immunoglobulins & $\begin{array}{l}\text { Bone } \\
\text { marrow }\end{array}$ \\
\hline $\begin{array}{l}\text { Boztug, } \\
2009\end{array}$ & P1 & Turkish & 6 & M & $\begin{array}{l}\text { ASD } \\
\text { Cryptorchidism } \\
\text { Increased venous } \\
\text { marking } \\
\text { Hepatoesplenomegaly }\end{array}$ & $\begin{array}{l}\text { ANC } 60-246 / \mu \mathrm{l} \\
\text { Intermittent } \\
\text { thrombocytopenia }\end{array}$ & NA & $\begin{array}{l}\text { Maturatio } \\
\text { stage of } \\
\text { promyelor }\end{array}$ \\
\hline $\begin{array}{l}\text { Boztug, } \\
2009\end{array}$ & $\mathrm{P} 2$ & Turkish & 3 & $\mathrm{~F}$ & $\begin{array}{l}\text { Cor triatriatum } \\
\text { Malformation of } \\
\text { pulmonary veins } \\
\text { Increased venous } \\
\text { marking } \\
\text { Hepato/esplenomegaly } \\
\text { Growth hormone } \\
\text { deficiency }\end{array}$ & ANC $54-240 / \mu 1$ & NA & $\begin{array}{l}\text { Maturatio } \\
\text { stage of } \\
\text { promyelor }\end{array}$ \\
\hline $\begin{array}{l}\text { Boztug, } \\
2009\end{array}$ & P3 & Turkish & 11 & $\mathrm{~F}$ & $\begin{array}{l}\text { ASD } \\
\text { Mitral insufficiency } \\
\text { Increased venous } \\
\text { marking } \\
\text { Hepatoesplenomegaly }\end{array}$ & $\begin{array}{l}\text { ANC } 0-61 / \mu \text { l } \\
\text { Intermittent } \\
\text { thrombocytopenia }\end{array}$ & NA & $\begin{array}{l}\text { Maturatio } \\
\text { stage of } \\
\text { promyelor }\end{array}$ \\
\hline $\begin{array}{l}\text { Boztug, } \\
2009\end{array}$ & P4 & Turkish & 6 & M & $\begin{array}{l}\text { ASD } \\
\text { Cryptorchidism } \\
\text { Increased venous } \\
\text { marking }\end{array}$ & ANC $0-322 / \mu 1$ & NA & $\begin{array}{l}\text { Maturatio } \\
\text { stage of } \\
\text { promyelor }\end{array}$ \\
\hline $\begin{array}{l}\text { Boztug, } \\
2009\end{array}$ & P5 & Turkish & 4 & M & $\begin{array}{l}\text { Increased venous } \\
\text { marking } \\
\text { Poor growth }\end{array}$ & $\begin{array}{l}\text { ANC } 25-84 / \mu \mathrm{l} \\
\text { Intermittent } \\
\text { thrombocytopenia }\end{array}$ & NA & $\begin{array}{l}\text { Maturatio } \\
\text { stage of } \\
\text { promyelor }\end{array}$ \\
\hline $\begin{array}{l}\text { Botzug, } \\
2009\end{array}$ & P6 & Turkish & 6 & $\mathrm{~F}$ & $\begin{array}{l}\text { ASD } \\
\text { Pulmonary valve } \\
\text { stenosis } \\
\text { Increased venous } \\
\text { marking }\end{array}$ & ANC $90-612 / \mu 1$ & NA & NA \\
\hline $\begin{array}{l}\text { Boztug, } \\
2009\end{array}$ & P7 & Greece & 7 & $\mathrm{~F}$ & $\begin{array}{l}\text { Inner ear hearing loss } \\
\text { Increased venous } \\
\text { marking }\end{array}$ & ANC $30-1280 / \mu 1$ & NA & NA \\
\hline $\begin{array}{l}\text { Boztug, } \\
2009\end{array}$ & P8 & Germany & 8 & $\mathrm{~F}$ & $\begin{array}{l}\text { ASD } \\
\text { Urachal fistula } \\
\text { Microcephaly } \\
\text { Increased venous } \\
\text { marking }\end{array}$ & $\begin{array}{l}\text { ANC } 75-210 / \mu \mathrm{l} \\
\text { Intermittent } \\
\text { thrombocytopenia }\end{array}$ & NA & NA \\
\hline $\begin{array}{l}\text { Boztug, } \\
2009\end{array}$ & P9 & France & 9 & $\mathrm{~F}$ & $\begin{array}{l}\text { Myopathy } \\
\text { Increased venous } \\
\text { marking }\end{array}$ & ANC $200-500 / \mu \mathrm{l}$ & NA & NA \\
\hline $\begin{array}{l}\text { Boztug, } \\
2009\end{array}$ & P10 & Germany & 10 & $M$ & $\begin{array}{l}\text { ASD } \\
\text { Cryptorchidism } \\
\text { Genital dysplasia } \\
\text { Microcephaly } \\
\text { Inner ear hearing loss } \\
\text { Increased venous } \\
\text { marking }\end{array}$ & $\begin{array}{l}\text { ANC } 0-3.000 / \mu 1 \\
\text { Intermittent } \\
\text { thrombocytopenia }\end{array}$ & NA & NA \\
\hline
\end{tabular}

Page 8/25 
Growth retardation

\begin{tabular}{|c|c|c|c|c|c|c|c|c|}
\hline $\begin{array}{l}\text { Boztug, } \\
2009\end{array}$ & P11 & Persian & 11 & M & $\begin{array}{l}\text { ASD } \\
\text { PDA }\end{array}$ & ANC $250-440 / \mu \mathrm{l}$ & NA & NA \\
\hline $\begin{array}{l}\text { Boztug, } \\
2009\end{array}$ & P12 & Lebanese & 12 & M & $\begin{array}{l}\text { Cryptorchidism } \\
\text { Bilateral inguinal } \\
\text { hernia } \\
\text { Cleft palate }\end{array}$ & ANC $615-2000 / \mu l$ & NA & NA \\
\hline $\begin{array}{l}\text { Eghbali, } \\
2009\end{array}$ & P13 & Iran & 0 & M & $\begin{array}{l}\text { Hydronephrosis of the } \\
\text { left kidney } \\
\text { ASD and PDA }\end{array}$ & ANC $234 / \mu 1$ & $\begin{array}{l}\operatorname{lgG} 672 \mathrm{mg} / \mathrm{dl} \\
(350-1180) \\
\operatorname{lgM} 131 \mathrm{ml} / \mathrm{dl} \\
\operatorname{lgA} 48 \mathrm{mg} / \mathrm{dl} \\
(36-165)\end{array}$ & $\begin{array}{l}\text { Maturatio } \\
\text { myeloid s }\end{array}$ \\
\hline $\begin{array}{l}\text { Dursun, } \\
2009\end{array}$ & P14 & Turkish & 0.3 & $\mathrm{~F}$ & $\begin{array}{l}\text { ASD } \\
\text { Mild PH } \\
\text { Hypertelorism } \\
\text { Pectus carinatum } \\
\text { Hypoplastic thymus }\end{array}$ & $\begin{array}{l}\text { ANC } 300-630 / \mu \mathrm{l} \\
\text { ALC } 336-3800 / \mu \mathrm{l} \\
\text { Platelets } 141.000- \\
222.000 / \mu \mathrm{l} \\
\mathrm{Hb} 6.5 \mathrm{~g} / \mathrm{dl}\end{array}$ & NA & $\begin{array}{l}\text { Hypocellu } \\
\text { normal di: } \\
\text { series }\end{array}$ \\
\hline $\begin{array}{l}\text { Durson, } \\
2009\end{array}$ & P15 & Turkish & 0.2 & M & $\begin{array}{l}\text { ASD } \\
\text { Mild PH } \\
\text { Pectus carinatum } \\
\text { Cryptorchidism } \\
\text { Hypoplastic thymus }\end{array}$ & $\begin{array}{l}\text { ANC } 112-6000 / \mu \mathrm{l} \\
\text { ALC 154-3680/ } \mu \mathrm{l} \\
\text { Platelets 35.000- } \\
446.000 / \mu \mathrm{l} \\
\mathrm{Hb} 7.8 \mathrm{~g} / \mathrm{dl}\end{array}$ & NA & $\begin{array}{l}\text { Dysplastiı } \\
\text { lineages, I } \\
\text { changes i } \\
\text { erythroid । } \\
\text { vacuoliza } \\
\text { series. }\end{array}$ \\
\hline $\begin{array}{l}\text { Arostegui, } \\
2009\end{array}$ & P16 & Moroccan & 22 & M & $\begin{array}{l}\text { ASD } \\
\text { Bilateral } \\
\text { cryptorchidism } \\
\text { Prominent } \\
\text { subcutaneous venous } \\
\text { circulation } \\
\text { Poor growth }\end{array}$ & $\begin{array}{l}\text { ANC } 50-540 / \mu \mathrm{l} \\
\mathrm{Hb} 9.5 \mathrm{~g} / \mathrm{dL}\end{array}$ & NA & $\begin{array}{l}\text { Paucity of } \\
\text { series bey } \\
\text { promyelo }\end{array}$ \\
\hline $\begin{array}{l}\text { Xia, } \\
2009\end{array}$ & P17 & USA & NA & NA & ASD & $\begin{array}{l}\text { Neutropenia } \\
\text { Intermittent } \\
\text { thrombocytopenia }\end{array}$ & NA & NA \\
\hline $\begin{array}{l}\text { Xia, } \\
2009\end{array}$ & P18 & USA & NA & NA & $\begin{array}{l}\text { ASD } \\
\text { Coronary aneurysm }\end{array}$ & $\begin{array}{l}\text { Intermittent } \\
\text { thrombocytopenia }\end{array}$ & NA & NA \\
\hline $\begin{array}{l}\text { McDermott, } \\
2010\end{array}$ & P19 & $\begin{array}{l}\text { USA } \\
\text { (Caucasian) }\end{array}$ & 13 & M & $\begin{array}{l}\text { Permeable foramen } \\
\text { ovale } \\
\text { Mild PHT } \\
\text { Cryptorchidism } \\
\text { Prominent superficial } \\
\text { veins } \\
\text { Sensorineural hearing } \\
\text { loss } \\
\text { Heart valve } \\
\text { abnormalities } \\
\text { Poor growth } \\
\text { Microcephaly } \\
\text { Ligamentous laxity } \\
\text { Bronchiectasias }\end{array}$ & ANC $50-900 / \mu l$ & NA & $\begin{array}{l}\text { Full myelc } \\
\text { Increased } \\
\text { CXCR4 }\end{array}$ \\
\hline
\end{tabular}

Page 9/25 


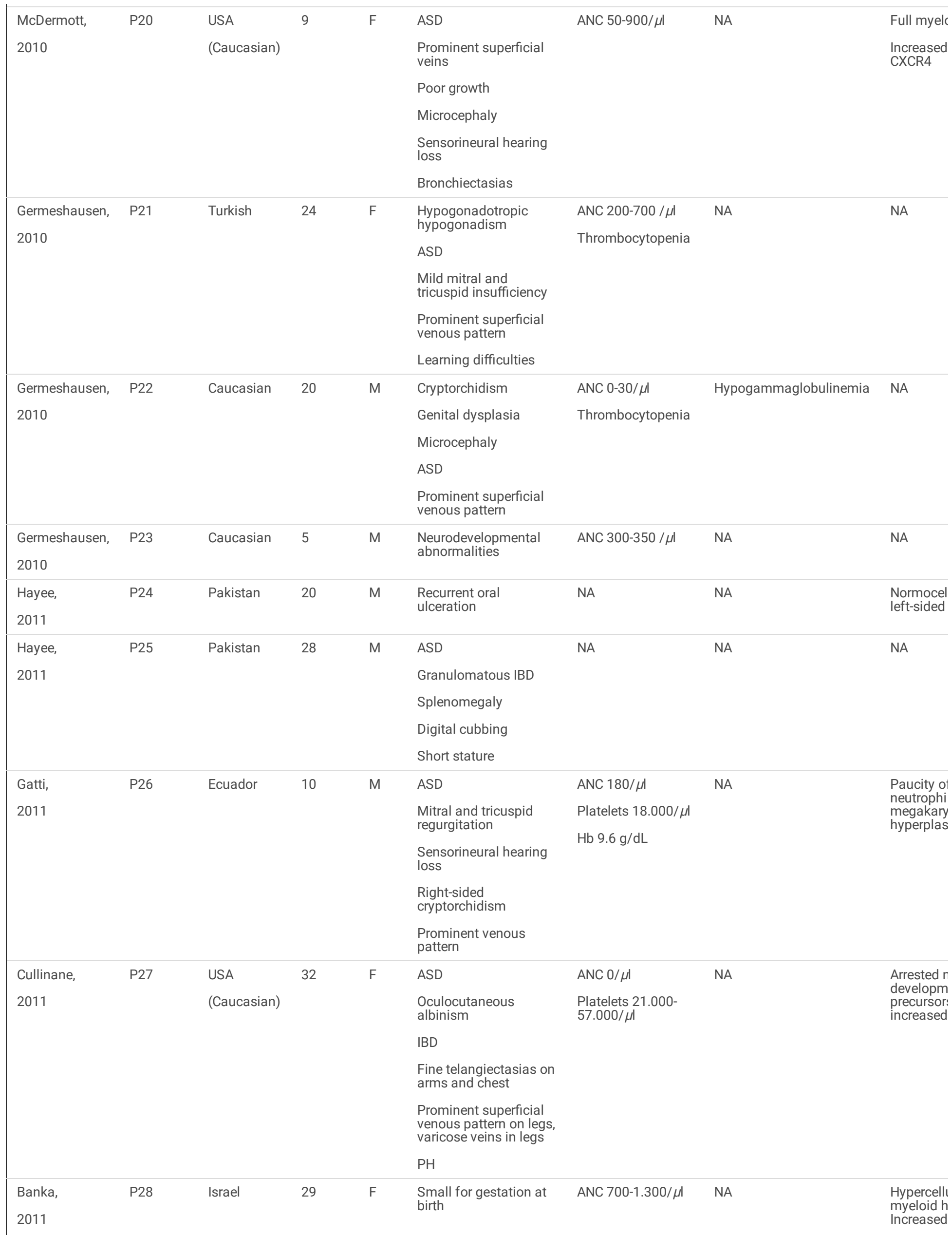

Page 10/25 


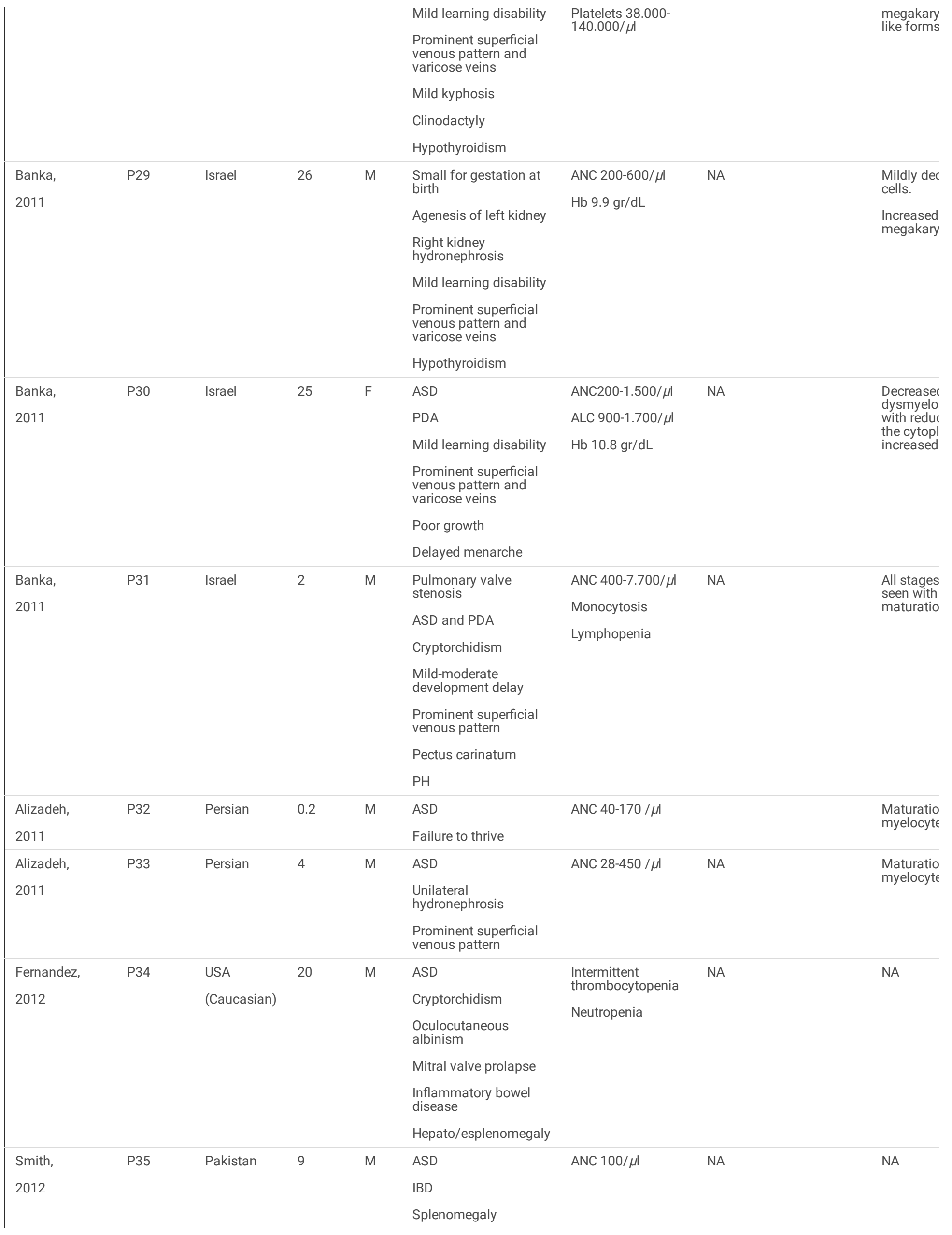

Page 11/25 


\begin{tabular}{|c|c|c|c|c|c|c|c|c|}
\hline & & & & & Short stature & & & \\
\hline $\begin{array}{l}\text { Smith, } \\
2012\end{array}$ & P36 & Turkey & NA & $\mathrm{F}$ & $\begin{array}{l}\text { Patent foramen ovale } \\
\text { Tricuspid insufficiency }\end{array}$ & $\mathrm{ANC}<100 / \mu \mathrm{l}$ & NA & NA \\
\hline $\begin{array}{l}\text { Smith, } \\
2012\end{array}$ & P37 & Pakistan & 13 & M & No abnormalities & ANC $400 / \mu \mathrm{l}$ & NA & Normocel \\
\hline $\begin{array}{l}\text { Smith, } \\
2012\end{array}$ & P38 & Pakistan & 3 & M & No abnormalities & ANC $450 / \mu \mathrm{l}$ & NA & $\begin{array}{l}\text { Normocel } \\
\text { morpholo }\end{array}$ \\
\hline $\begin{array}{l}\text { Boztug, } \\
2012\end{array}$ & P39 & Arab & 12 & $\mathrm{~F}$ & $\begin{array}{l}\text { ASD } \\
\text { Small PDA } \\
\text { Prominent superficial } \\
\text { venous pattern } \\
\text { Discontinuous labia } \\
\text { majora and minora }\end{array}$ & $\begin{array}{l}\text { ANC } 200 / \mu \mathrm{l} \\
\text { Platelets } 58.000- \\
414.000 / \mu \mathrm{l}\end{array}$ & NA & $\begin{array}{l}\text { Left shift } \\
\text { reduced } n \\
\text { mature } n \epsilon\end{array}$ \\
\hline $\begin{array}{l}\text { Boztug, } \\
2012\end{array}$ & P40 & Hispanic & 9 & M & $\begin{array}{l}\text { ASD } \\
\text { Prominent superficial } \\
\text { venous pattern } \\
\text { Frontal bossing } \\
\text { Upturned nose } \\
\text { Bilateral } \\
\text { cryptorchidism } \\
\text { Growth hormone } \\
\text { deficiency }\end{array}$ & $\begin{array}{l}\text { ANC } 0-123 / \mu \mathrm{l} \\
\text { Platelets } 13.000- \\
120.000 / \mu \mathrm{l}\end{array}$ & NA & $\begin{array}{l}\text { Left shift } \\
\text { reduced } n \\
\text { mature } n \epsilon\end{array}$ \\
\hline $\begin{array}{l}\text { Boztug, } \\
2012\end{array}$ & P41 & Caucasian & 9 & M & $\begin{array}{l}\text { ASD } \\
\text { Prominent superficial } \\
\text { venous pattern } \\
\text { Hypoplastic nipples } \\
\text { Micropenis } \\
\text { Erythropachydermia }\end{array}$ & ANC $100 / \mu \mathrm{l}$ & NA & Not done \\
\hline $\begin{array}{l}\text { Boztug, } \\
2012\end{array}$ & P42 & Caucasian & 11 & M & $\begin{array}{l}\text { ASD } \\
\text { PDA } \\
\text { Bicuspid aortic valve } \\
\text { Prominent superficial } \\
\text { venous pattern } \\
\text { Micropenis } \\
\text { Cryptorchidism } \\
\text { Erythropachydermia } \\
\text { Mild developmental } \\
\text { delay }\end{array}$ & $\begin{array}{l}\text { ANC } 276 / \mu \mathrm{l} \\
\text { Platelets } 44.000- \\
342.000 / \mu \mathrm{l}\end{array}$ & NA & $\begin{array}{l}\text { Left shift } \\
\text { reduced } n \\
\text { mature } n \epsilon\end{array}$ \\
\hline $\begin{array}{l}\text { Boztug, } \\
2012\end{array}$ & P43 & Caucasian & 7 & M & $\begin{array}{l}\text { ASD } \\
\text { Prominent superficial } \\
\text { venous pattern } \\
\text { Growth hormone } \\
\text { deficiency } \\
\text { Triangular face } \\
\text { Left inguinal hernia }\end{array}$ & $\begin{array}{l}\text { ANC } 0-2.200 / \mu 1 \\
\text { Platelets } 65.000- \\
635.000 / \mu 1\end{array}$ & NA & $\begin{array}{l}\text { Hypocellu } \\
\text { left shift c } \\
\text { with few r } \\
\text { neutrophi }\end{array}$ \\
\hline $\begin{array}{l}\text { Boztug, } \\
2012\end{array}$ & P44 & Hispanic & 11 & $M$ & $\begin{array}{l}\text { ASD } \\
\text { Mitral and tricuspid } \\
\text { regurgitation } \\
\text { Prominent superficial } \\
\text { venous pattern } \\
\text { Right cryptorchidism }\end{array}$ & $\begin{array}{l}\text { ANC } 180 / \mu \mathrm{l} \\
\text { Platelets } 16.000- \\
553.000 / \mu \mathrm{l}\end{array}$ & NA & $\begin{array}{l}\text { Maturatio } \\
\text { myelocyt } \\
\text { stage }\end{array}$ \\
\hline
\end{tabular}

Page 12/25 
Bilateral inner ear

hearing loss

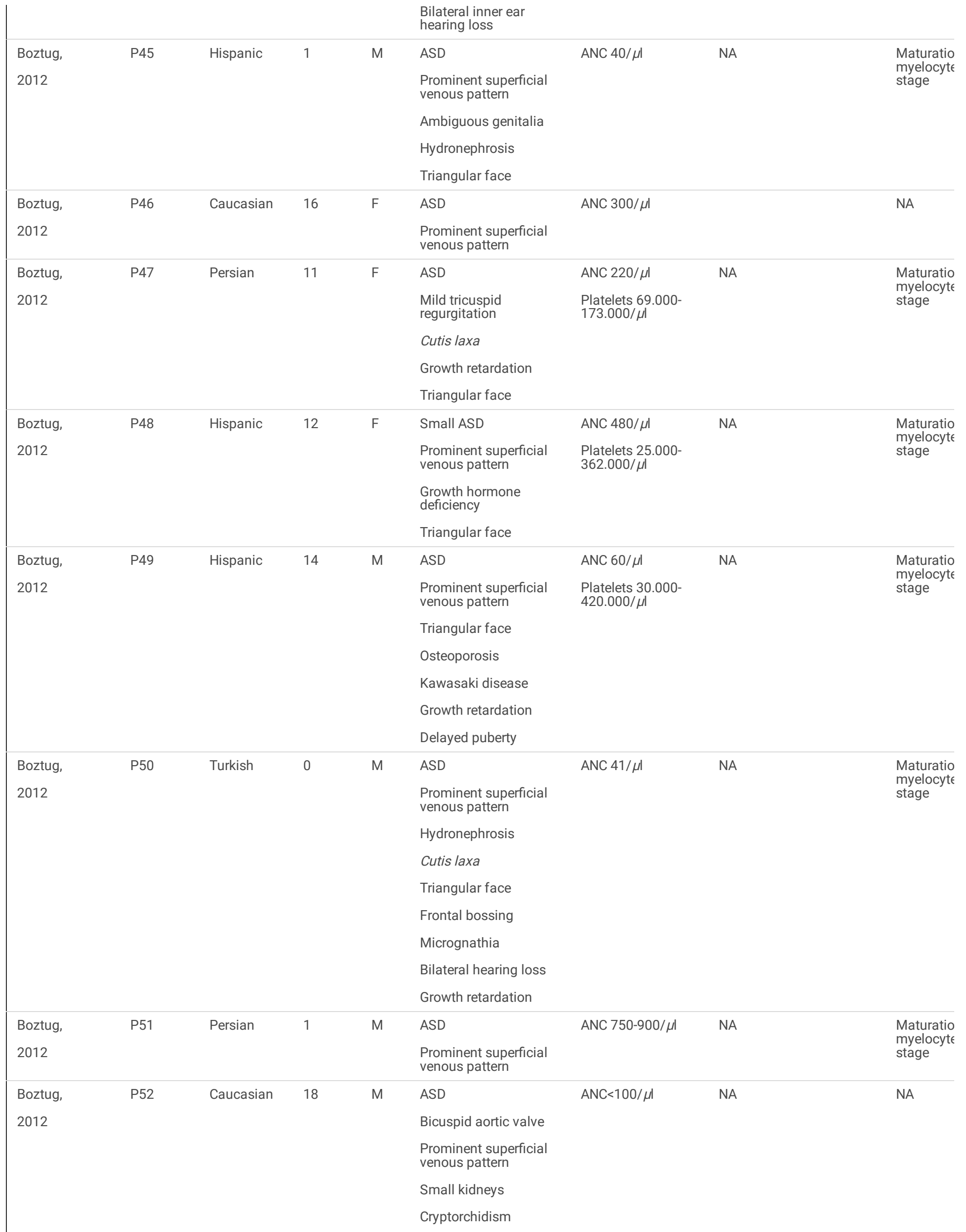

Page 13/25 
Delayed puberty

Growth retardation

Massive splenomegaly

\begin{tabular}{|c|c|c|c|c|c|c|c|c|}
\hline \multirow[t]{2}{*}{$\begin{array}{l}\text { Boztug, } \\
2012\end{array}$} & \multirow[t]{2}{*}{ P53 } & \multirow[t]{2}{*}{ Pakistani } & \multirow[t]{2}{*}{1} & \multirow[t]{2}{*}{$\mathrm{F}$} & $\begin{array}{l}\text { Hypoplastic left } \\
\text { ventricle }\end{array}$ & \multirow[t]{2}{*}{ ANC $200-400$} & \multirow[t]{2}{*}{ NA } & \multirow[t]{2}{*}{$\begin{array}{l}\text { Left shif } \\
\text { strongly } \\
\text { of matur }\end{array}$} \\
\hline & & & & & Congenital ptosis & & & \\
\hline
\end{tabular}

Growth retardation

\begin{tabular}{|c|c|c|c|c|c|c|c|c|}
\hline \multirow[t]{4}{*}{$\begin{array}{l}\text { Boztug, } \\
2012\end{array}$} & \multirow[t]{4}{*}{ P54 } & \multirow[t]{4}{*}{ Caucasian } & \multirow[t]{4}{*}{7} & \multirow[t]{4}{*}{ M } & $\begin{array}{l}\text { ASD } \\
\text { Prominent superficial } \\
\text { venous pattern }\end{array}$ & \multirow[t]{4}{*}{$\begin{array}{l}\text { ANC } 200 / \mu \mathrm{l} \\
\text { Platelets } 97.000- \\
332.000 / \mu 1\end{array}$} & \multirow[t]{4}{*}{ NA } & \multirow[t]{4}{*}{$\begin{array}{l}\text { Left shift } \\
\text { strongly r } \\
\text { of mature }\end{array}$} \\
\hline & & & & & Cryptorchidism & & & \\
\hline & & & & & Right ptosis & & & \\
\hline & & & & & Splenomegaly & & & \\
\hline \multirow[t]{8}{*}{ Aytekin, 2013} & \multirow[t]{8}{*}{ P55 } & \multirow[t]{8}{*}{ Turkey } & \multirow[t]{8}{*}{13} & \multirow[t]{8}{*}{$\mathrm{F}$} & Mild mitral & \multirow{8}{*}{$\begin{array}{l}\mathrm{Hb} 9.2 \mathrm{~g} / \mathrm{dL} \\
\text { ANC } 200 / \mu \mathrm{l}\end{array}$} & \multirow[t]{8}{*}{ Normal } & Myelokatl \\
\hline & & & & & & & & \multirow{7}{*}{$\begin{array}{l}\text { Hypercell } \\
\text { myeloid } \mathrm{h} \\
\text { without } \mathrm{n}\end{array}$} \\
\hline & & & & & Fromtal Dossing & & & \\
\hline & & & & & Depressed nasal bridge & & & \\
\hline & & & & & Upturned nose & & & \\
\hline & & & & & Retrognathia & & & \\
\hline & & & & & $\begin{array}{l}\text { Prominent superficial } \\
\text { venous pattern on } \\
\text { neck, chest, abdomen }\end{array}$ & & & \\
\hline & & & & & $\begin{array}{l}\text { Poorly developed } \\
\text { secondary sexual } \\
\text { characteristics }\end{array}$ & & & \\
\hline \multirow{3}{*}{$\begin{array}{l}\text { Banka, } \\
2013\end{array}$} & \multirow[t]{3}{*}{ P56 } & \multirow[t]{3}{*}{ Pakistan } & \multirow[t]{3}{*}{10} & \multirow[t]{3}{*}{$\mathrm{F}$} & $\begin{array}{l}\text { No prominent } \\
\text { superficial venous }\end{array}$ & \multirow{3}{*}{$\begin{array}{l}\text { ANC 320-1.999/ } 1 \mathrm{l} \\
\text { Platelets } 131.000- \\
201.000 / \mu \mathrm{l}\end{array}$} & \multirow[t]{3}{*}{ NA } & \multirow[t]{3}{*}{ Normocel } \\
\hline & & & & & 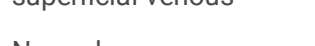 & & & \\
\hline & & & & & $\begin{array}{l}\text { Normal } \\
\text { echocardiogram }\end{array}$ & & & \\
\hline \multirow{2}{*}{$\begin{array}{l}\text { Banka, } \\
2013\end{array}$} & \multirow[t]{2}{*}{ P57 } & \multirow[t]{2}{*}{ Pakistan } & \multirow[t]{2}{*}{13} & \multirow[t]{2}{*}{$\mathrm{F}$} & $\begin{array}{l}\text { No prominent } \\
\text { superficial venous }\end{array}$ & \multirow[t]{2}{*}{ ANC $280-1080 / \mu 1$} & \multirow[t]{2}{*}{ NA } & Normocel \\
\hline & & & & & $\begin{array}{l}\text { Normal } \\
\text { echocardiogram }\end{array}$ & & & \\
\hline Banka, & P58 & & 8 & $\mathrm{~F}$ & $\begin{array}{l}\text { No prominent } \\
\text { superficial venous }\end{array}$ & ANC $120-570 / \mu \mathrm{l}$ & NA & Normocel \\
\hline 2013 & & Britain & & & $\begin{array}{l}\text { Normal } \\
\text { echocardiogram }\end{array}$ & $\begin{array}{l}\text { Lymphocytes 1070- } \\
1100 / \mu 1\end{array}$ & & \\
\hline Banka, & P59 & Great & 18 & $\mathrm{~F}$ & No prominent & ANC $110-670 / \mu \mathrm{l}$ & NA & Normocel \\
\hline 2013 & & Britain & & & & Lymphocytes 660- & & \\
\hline & & & & & $\begin{array}{l}\text { Normal } \\
\text { echocardiogram }\end{array}$ & $1150 / \mu \mathrm{l}$ & & \\
\hline Bégin, & P60 & Canada & 0.6 & $\mathrm{~F}$ & Mitral valve & ALC $600 / \mu \mathrm{l}$ & lgG $2340 \mathrm{mg} / \mathrm{dl}$ & Normal he \\
\hline 2013 & & & & & & $(1.500-2.800)$ & $(520-1520)$ & \\
\hline & & & & & $\begin{array}{l}\text { Prominent superficial } \\
\text { venous }\end{array}$ & T-cell lymphopenia & lgA 117 mg/dl & \\
\hline & & & & & IBD & & $(65-400)$ & \\
\hline & & & & & Growth delay & & lgM 183 mg/dl & \\
\hline & & & & & & & $(22-280)$ & \\
\hline
\end{tabular}

\begin{tabular}{|c|c|c|c|c|c|c|c|c|}
\hline $\begin{array}{l}\text { Estévez, } \\
2013\end{array}$ & P61 & Caucasian & 11 & $M$ & $\begin{array}{l}\text { Cryptorchidism } \\
\text { Prominent superficial } \\
\text { veins }\end{array}$ & $\begin{array}{l}\text { ANC 45-1.200 / } \mu \mathrm{l} \\
\text { Intermittent } \\
\text { thrombocytopenia }\end{array}$ & NA & \\
\hline $\begin{array}{l}\text { Alangeri, } \\
2013\end{array}$ & P62 & $\begin{array}{l}\text { Saudi } \\
\text { Arabia }\end{array}$ & 12 & $M$ & $\begin{array}{l}\text { Asthma } \\
\text { Bicuspid aortic valve }\end{array}$ & $\begin{array}{l}\text { ANC 7-500/ } \mu \mathrm{l} \\
\text { Intermittent } \\
\text { thrombocytopenia }\end{array}$ & NA & $\begin{array}{l}\text { Active trili } \\
\text { hematopc } \\
\text { evidence । } \\
\text { arrest. }\end{array}$ \\
\hline
\end{tabular}

Page 14/ 25 
Inguinal hernia

\begin{tabular}{|c|c|c|c|c|c|c|c|c|}
\hline $\begin{array}{l}\text { Alangeri, } \\
2013\end{array}$ & P63 & $\begin{array}{l}\text { Saudi } \\
\text { Arabia }\end{array}$ & 10 & $\mathrm{~F}$ & $\begin{array}{l}\text { ASD } \\
\text { Aphthous stomatitis } \\
\text { Abdominal pain } \\
\text { Asthma }\end{array}$ & $\begin{array}{l}\text { ANC } 210 / \mu \text { l } \\
\text { Intermittent } \\
\text { thrombocytopenia }\end{array}$ & NA & NA \\
\hline $\begin{array}{l}\text { Alangeri, } \\
2013\end{array}$ & P64 & $\begin{array}{l}\text { Saudi } \\
\text { Arabia }\end{array}$ & NB & M & Septic shock & NA & NA & NA \\
\hline $\begin{array}{l}\text { Alangeri, } \\
2013\end{array}$ & P65 & $\begin{array}{l}\text { Saudi } \\
\text { Arabia }\end{array}$ & 9 & $\mathrm{~F}$ & Asthma & ANC $110-600 / \mu \mathrm{l}$ & $\begin{array}{l}\text { Normal lymphocyte } \\
\text { subsets }\end{array}$ & No maturi \\
\hline $\begin{array}{l}\text { Alangeri, } \\
2013\end{array}$ & P66 & $\begin{array}{l}\text { Saudi } \\
\text { Arabia }\end{array}$ & 2 & M & NA & ANC $180 / \mu \mathrm{l}$ & & $\begin{array}{l}\text { Active gra } \\
\text { no maturc }\end{array}$ \\
\hline Arikoglu, 2014 & P67 & Turkey & 3 & $\mathrm{~F}$ & $\begin{array}{l}\text { ASD and PDA } \\
\text { Frontal bossing } \\
\text { Depressed nasal bridge } \\
\text { Retrognathia } \\
\text { Prominent superficial } \\
\text { venous pattern on } \\
\text { chest and abdomen } \\
\text { Hepatomegaly } \\
\text { Bilateral cortical renal } \\
\text { cysts } \\
\text { PH }\end{array}$ & $\begin{array}{l}\text { ANC } 600 / \mu \mathrm{l} \\
\mathrm{Hb} 6 \mathrm{~g} / \mathrm{dL} \\
\text { Platelets } 89000 / \mu \mathrm{l}\end{array}$ & $\begin{array}{l}\text { IgG } 889 \mathrm{mg} / \mathrm{dl}(604-1940) \\
\operatorname{lgA} 50 \mathrm{mg} / \mathrm{dl} \\
(26-296 \mathrm{mg} / \mathrm{dl}) \\
\mathrm{IgM} 130 \mathrm{mg} / \mathrm{dl} \\
(71-235) \\
\operatorname{lgE}<17 \mathrm{KU} / \mathrm{L} \\
(0-100) \\
\text { CD4+ T cells } 260-436 \\
\mathrm{~mm}{ }^{3} \\
(500-2400) \\
\text { CD19+ T cells } 80-166 \\
\mathrm{~mm}^{3} \\
(200-2100)\end{array}$ & Normocel \\
\hline $\begin{array}{l}\text { Kaya, } \\
2014\end{array}$ & P68 & Turkey & 0.4 & $\mathrm{~F}$ & $\begin{array}{l}\text { Patent foramen ovale } \\
\text { Minimal tricuspid } \\
\text { insufficiency } \\
\text { Pancolitis, IBD }\end{array}$ & ANC $80 / \mu 1$ & Normal & Normal \\
\hline $\begin{array}{l}\text { Kaya, } \\
2014\end{array}$ & P69 & Turkey & 1 & $\mathrm{~F}$ & $\begin{array}{l}\text { ASD } \\
\text { Osteoporosis }\end{array}$ & ANC $100 / \mu \mathrm{l}$ & NA & NA \\
\hline $\begin{array}{l}\text { Desplantes, } \\
2014\end{array}$ & P70 & France & NB & $\mathrm{F}$ & $\begin{array}{l}\text { Aortic insufficiency } \\
\text { Grade III RVU, urethral } \\
\text { duplication } \\
\text { Prominent veins } \\
\text { Cutis laxa } \\
\text { Frontal bossing } \\
\text { Thick lips } \\
\text { Hypothyroidism } \\
\text { Neurodevelopment } \\
\text { difficulties } \\
\text { Leukemia }\end{array}$ & $\begin{array}{l}\text { ANC } 280 / \mu l \\
\text { Mild } \\
\text { thrombocytopenia } \\
\text { Mild anemia }\end{array}$ & NA & NA \\
\hline $\begin{array}{l}\text { Desplantes, } \\
2014\end{array}$ & P71 & France & NB & M & $\begin{array}{l}\text { ASD } \\
\text { Bilateral } \\
\text { cryptorchidism } \\
\text { Hypospadias }\end{array}$ & ANC $383 / \mu 1$ & NA & NA \\
\hline
\end{tabular}

Page 15/ 25 
Prominent veins

Cutis laxa

Frontal bossing

Thick lips

Neurodevelopment difficulties

\begin{tabular}{|c|c|c|c|c|c|c|c|c|}
\hline \multirow{6}{*}{$\begin{array}{l}\text { Desplantes, } \\
2014\end{array}$} & \multirow[t]{6}{*}{ P72 } & \multirow[t]{6}{*}{ France } & \multirow[t]{6}{*}{ NB } & \multirow[t]{6}{*}{$\mathrm{F}$} & \multirow{6}{*}{$\begin{array}{l}\text { ASD } \\
\text { Bilateral grade I RVU } \\
\text { Thick lips } \\
\text { Prominent veins } \\
\text { Cutis laxa } \\
\begin{array}{l}\text { Neurodevelopment } \\
\text { difficulties }\end{array}\end{array}$} & ANC $411 / \mu \mathrm{l}$ & \multirow[t]{6}{*}{ NA } & \multirow[t]{6}{*}{ NA } \\
\hline & & & & & & \multirow{5}{*}{$\begin{array}{l}\text { Mild } \\
\text { thrombocytopenia } \\
\text { Mild anemia }\end{array}$} & & \\
\hline & & & & & & & & \\
\hline & & & & & & & & \\
\hline & & & & & & & & \\
\hline & & & & & & & & \\
\hline \multirow{9}{*}{$\begin{array}{l}\text { Desplantes, } \\
2014\end{array}$} & \multirow[t]{9}{*}{ P73 } & \multirow[t]{9}{*}{ France } & \multirow[t]{9}{*}{ NB } & \multirow[t]{9}{*}{ M } & PDA overriding aorta & ANC $550 / \mu \mathrm{l}$ & \multirow[t]{9}{*}{ NA } & \multirow[t]{9}{*}{ NA } \\
\hline & & & & & Grade III RVU & \multirow[t]{8}{*}{ Mild anemia } & & \\
\hline & & & & & Right cryptorchidism & & & \\
\hline & & & & & Prominent veins & & & \\
\hline & & & & & IBD & & & \\
\hline & & & & & Cutis laxa & & & \\
\hline & & & & & $\mathrm{PH}$ & & & \\
\hline & & & & & Thick lips & & & \\
\hline & & & & & $\begin{array}{l}\text { Neurodevelopment } \\
\text { difficulties }\end{array}$ & & & \\
\hline \multirow{8}{*}{$\begin{array}{l}\text { Desplantes, } \\
2014\end{array}$} & \multirow[t]{8}{*}{ P74 } & \multirow[t]{8}{*}{ France } & \multirow[t]{8}{*}{ NB } & \multirow[t]{8}{*}{ M } & Cryptorchidism & ANC $314 / \mu 1$ & \multirow[t]{8}{*}{ NA } & \multirow[t]{8}{*}{ NA } \\
\hline & & & & & Bilateral RVU & \multirow[t]{7}{*}{ Mild anemia } & & \\
\hline & & & & & Megaureter & & & \\
\hline & & & & & Prominent veins & & & \\
\hline & & & & & Cutis laxa & & & \\
\hline & & & & & Bilateral hearing loss & & & \\
\hline & & & & & Prominent lips & & & \\
\hline & & & & & $\begin{array}{l}\text { Neurodevelopment } \\
\text { difficulties }\end{array}$ & & & \\
\hline
\end{tabular}

\begin{tabular}{|c|c|c|c|c|c|c|c|c|}
\hline $\begin{array}{l}\text { Desplantes, } \\
2014\end{array}$ & P75 & France & 0.7 & $M$ & $\begin{array}{l}\text { Prominent veins } \\
\text { Kabuki syndrome like } \\
\text { Cerebral palsy }\end{array}$ & $\begin{array}{l}\text { ANC } 540 / \mu \mathrm{l} \\
\text { Mild anemia }\end{array}$ & $\begin{array}{l}\text { IgG } 1870 \text { mg/dl (608- } \\
1229) \\
\text { lgA } 170 \text { mg/dl (33-200) } \\
\text { lgM } 170 \text { mg/dl (46-197) }\end{array}$ & NA \\
\hline & & & & & & & $\begin{array}{l}\text { CD3+ } 1960(2100-6200) \\
\text { CD4+ } 812(1300-3400) \\
\text { CD8+ } 756(490-1300) \\
\text { CD19 } 364(390-1400)\end{array}$ & \\
\hline $\begin{array}{l}\text { Desplantes, } \\
2014\end{array}$ & P76 & France & NB & $M$ & $\begin{array}{l}\text { Aortic insufficiency } \\
\text { Cryptorchidism } \\
\text { Micropenis }\end{array}$ & $\begin{array}{l}\text { ANC } 405 / \mu \mathrm{l} \\
\text { Mild } \\
\text { thrombocytopenia }\end{array}$ & NA & NA \\
\hline
\end{tabular}




\begin{tabular}{|c|c|c|c|c|c|c|c|c|}
\hline & & & & & $\begin{array}{l}\text { Prominent veins } \\
\text { IBD } \\
\text { Inguinal hernia }\end{array}$ & Mild anemia & & \\
\hline \multirow{8}{*}{$\begin{array}{l}\text { Desplantes, } \\
2014\end{array}$} & \multirow[t]{8}{*}{ P77 } & \multirow[t]{8}{*}{ France } & \multirow[t]{8}{*}{ NB } & \multirow[t]{8}{*}{ M } & ASD & \multirow[t]{8}{*}{ ANC $410 / \mu l$} & $\operatorname{lgG} 435$ mg/dl (332-1160) & \multirow[t]{8}{*}{ NA } \\
\hline & & & & & Aortic insufficiency & & IgA 32 mg/dl (14-105) & \\
\hline & & & & & Cryptorchidism & & $\lg M 34$ (45-190) & \\
\hline & & & & & Prominent veins & & & \\
\hline & & & & & Umbilical hernia & & CD3+ 1891 (2100-6200) & \\
\hline & & & & & \multirow[t]{3}{*}{ Frontal bossing } & & CD4 1178 (1300-3400) & \\
\hline & & & & & & & CD8 $682(620-2000)$ & \\
\hline & & & & & & & CD19 651 (720-2600) & \\
\hline \multirow{4}{*}{$\begin{array}{l}\text { Desplantes, } \\
2014\end{array}$} & \multirow[t]{4}{*}{ P78 } & \multirow[t]{4}{*}{ France } & \multirow[t]{4}{*}{ NB } & \multirow[t]{4}{*}{$\mathrm{F}$} & Tricuspid regurgitation & \multirow[t]{4}{*}{ ANC $400 / \mu l$} & \multirow[t]{4}{*}{ NA } & \multirow[t]{4}{*}{ NA } \\
\hline & & & & & Bilateral RVU & & & \\
\hline & & & & & Bilateral deafness & & & \\
\hline & & & & & NA & & & \\
\hline \multirow{7}{*}{$\begin{array}{l}\text { Desplantes, } \\
2014\end{array}$} & \multirow[t]{7}{*}{ P79 } & \multirow[t]{7}{*}{ France } & \multirow[t]{7}{*}{0.7} & \multirow[t]{7}{*}{$\mathrm{F}$} & ASD & \multirow{7}{*}{$\begin{array}{l}\text { ANC } 700 / \mu \mathrm{l} \\
\text { Severe anemia }\end{array}$} & IgG970 mg/dl (768-1630) & \multirow[t]{7}{*}{ NA } \\
\hline & & & & & $\mathrm{PH}$ & & IgA 170 mg/dl (68-378) & \\
\hline & & & & & \multirow[t]{5}{*}{ Broad nasal bridge } & & IgM 100 mg/dl (60-230) & \\
\hline & & & & & & & CD3+ 378 (1200-2000) & \\
\hline & & & & & & & CD4+ 252 (530-1300) & \\
\hline & & & & & & & CD8+ 98 (330-920) & \\
\hline & & & & & & & CD19+ $49(110-570)$ & \\
\hline \multirow{3}{*}{$\begin{array}{l}\text { Desplantes, } \\
2014\end{array}$} & \multirow[t]{3}{*}{ P80 } & France & NB & $\mathrm{F}$ & ASD & ANC $520 / \mu 1$ & NA & NA \\
\hline & & & & & Prominent veins & $\begin{array}{l}\text { Severe } \\
\text { thrombocytopenia }\end{array}$ & & \\
\hline & & & & & & Mild anemia & & \\
\hline Desplantes, & P81 & France & 4.5 & M & ASD & ANC $160 / \mu l$ & NA & NA \\
\hline 2014 & & & & & Cryptorchidism & Mild anemia & & \\
\hline & & & & & Prominent veins & & & \\
\hline & & & & & Delayed puberty & & & \\
\hline Desplantes, & P82 & France & NB & M & Prominent veins & ANC $690 / \mu \mathrm{l}$ & $\begin{array}{l}\text { lgG1560 mg/dl (420- } \\
1090)\end{array}$ & \\
\hline 2014 & & & & & Pierre Robin sequence & $\begin{array}{l}\text { Mild } \\
\text { thrombocytopenia }\end{array}$ & IgA 55 mg/dl (22-157) & \\
\hline & & & & & $\begin{array}{l}\text { Major intelectual } \\
\text { disability }\end{array}$ & Mild anemia & IgM 70 mg/dl (45-263) & \\
\hline & & & & & & & CD3+ 698 (1400-3700) & \\
\hline & & & & & & & CD4+ $274(700-2200)$ & \\
\hline & & & & & & & CD8+ 332 (490-1300) & \\
\hline & & & & & & & CD19+ 58 (390-1400) & \\
\hline Notarangelo, & P83 & Italy & 13 & $\mathrm{~F}$ & Mitral valve prolapse & ANC $200 / \mu 1$ & IgG 1240 mg/dl (231-947) & Global hy \\
\hline 2014 & & & & & Inguinal hernia & Mild anemia & lgA 54 mg/dl (8-74) & Myeloid $\mathrm{h}$ \\
\hline & & & & & $\begin{array}{l}\text { Hypergonadotrophic } \\
\text { hypogonadism }\end{array}$ & $\begin{array}{l}\text { Intermittent } \\
\text { thrombocytopenia }\end{array}$ & $\operatorname{IgM} 79(26-210)$ & Maturatio \\
\hline & & & & & Frontal bossing & & & $\begin{array}{l}\text { Paucity of } \\
\text { neutrophi }\end{array}$ \\
\hline
\end{tabular}

Page 17/25 
Retrognathia

Prominent superficial

venous pattern

\begin{tabular}{|c|c|c|c|c|c|c|c|c|}
\hline \multirow{5}{*}{$\begin{array}{l}\text { Notarangelo, } \\
2014\end{array}$} & \multirow[t]{5}{*}{ P84 } & \multirow[t]{5}{*}{ Turkey } & \multirow[t]{5}{*}{2} & \multirow[t]{5}{*}{ M } & Facial dysmorphisms & \multirow[t]{5}{*}{ ANC $60 / \mu \mathrm{l}$} & IgG 974 mg/dl (462-1710) & \multirow[t]{5}{*}{$\begin{array}{l}\text { Delayed g } \\
\text { maturatio }\end{array}$} \\
\hline & & & & & Prominent veins & & \multirow{4}{*}{$\begin{array}{l}\text { IgA } 64 \text { mg/dl (27-173) } \\
\text { IgM } 118 \text { mg/dl (62-257) }\end{array}$} & \\
\hline & & & & & $\begin{array}{l}\text { Sensorineural hearing } \\
\text { loss }\end{array}$ & & & \\
\hline & & & & & Micropenis & & & \\
\hline & & & & & Coronal hypospadias & & & \\
\hline \multirow{14}{*}{$\begin{array}{l}\text { Kiykim, } \\
2015\end{array}$} & \multirow[t]{14}{*}{ P85 } & \multirow[t]{14}{*}{ Turkey } & \multirow[t]{14}{*}{19} & \multirow[t]{14}{*}{ M } & ASD & \multirow{14}{*}{$\begin{array}{l}\text { ANC } 500 / \mu l \\
\text { ALC } 400 / \mu l\end{array}$} & $\begin{array}{l}\operatorname{lgG} 2520 \text { mg/dl (913- } \\
1884)\end{array}$ & \multirow{14}{*}{$\begin{array}{l}\text { Hypercellı } \\
\text { marrow, } n \\
\text { granulocy }\end{array}$} \\
\hline & & & & & $\begin{array}{l}\text { Prominent superficial } \\
\text { venous pattern }\end{array}$ & & $\operatorname{lgM} 89$ mg/dl & \\
\hline & & & & & Osteopenia & & $(88-322)$ & \\
\hline & & & & & Puberal delay & & $\operatorname{lgA} 67$ mg/dl & \\
\hline & & & & & IBD-like & & \multirow[t]{2}{*}{$(139-378)$} & \\
\hline & & & & & Bronchiectasis & & & \\
\hline & & & & & & & \multirow{2}{*}{$\begin{array}{l}\text { CD4+T cells } 124 / \mu \mathrm{l} \\
(500-2000)\end{array}$} & \\
\hline & & & & & & & & \\
\hline & & & & & & & \multirow{2}{*}{$\begin{array}{l}\text { CD8+ T cells } 140 / \mu \mathrm{l} \\
(200-1200)\end{array}$} & \\
\hline & & & & & & & & \\
\hline & & & & & & & \multirow{2}{*}{$\begin{array}{l}\text { CD } 19+20 \text { cells } 20 / \mu l \\
(64-820)\end{array}$} & \\
\hline & & & & & & & & \\
\hline & & & & & & & $\mathrm{CD} 16+568 / \mu \mathrm{l}$ & \\
\hline & & & & & & & $(100-1200)$ & \\
\hline \multirow{6}{*}{$\begin{array}{l}\text { Kiykim, } \\
2015\end{array}$} & \multirow[t]{6}{*}{ P86 } & \multirow[t]{6}{*}{ Turkey } & 11 & $\mathrm{~F}$ & ASD and PDA & ANC $300 / \mu \mathrm{l}$ & $\operatorname{lgG} 2000$ mg/dl & Hypercellı \\
\hline & & & & & Osteoporosis & ALC $1400 / \mu l$ & (835-2894) & granulope \\
\hline & & & & & $\begin{array}{l}\text { Prominent superficial } \\
\text { venous pattern }\end{array}$ & & lgM 237 mg/dl & lineage. \\
\hline & & & & & & & $(47-484)$ & \\
\hline & & & & & 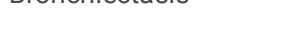 & & $\operatorname{lgA} 56$ mg/dl & \\
\hline & & & & & & & $(67-433)$ & \\
\hline Kiykim, & P87 & Turkey & 16 & $\mathrm{~F}$ & $\begin{array}{l}\text { Mild mitral valve } \\
\text { insufficiency }\end{array}$ & ANC $340 / \mu \mathrm{l}$ & lgG 1930 mg/dl & $\begin{array}{l}\text { Mild dysp } \\
\text { granulocy }\end{array}$ \\
\hline 2015 & & & & & Octonnorosic & ALC $1700 / \mu \mathrm{l}$ & $(676-2197)$ & Hunnonar \\
\hline & & & & & Dupertaldona & $\mathrm{CD} 19+2085 / \mu \mathrm{l}$ & $\operatorname{lgM} 98$ mg/dl & neutrophi \\
\hline & & & & & 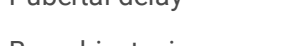 & $(120-740)$ & $(75-448)$ & \\
\hline & & & & & Droncriectasis & & $\lg A 53$ mg/dl & \\
\hline & & & & & & & $(108-447)$ & \\
\hline Mistry, & P88 & Great & 12 & M & Arthritis & Cyclic neutropenia & Polyclonal increase in IgG & No defect \\
\hline 2017 & & Britain & & & IBD-like & $\begin{array}{l}\text { Normocytic } \\
\text { anemia }\end{array}$ & & \\
\hline Bolton, & P89 & Great & 1.4 & M & IBD & Neutropenia & lgG 1660 mg/dl & NA \\
\hline 2019 & & & & & & ALC $490 / \mu 1$ & $(660-1.200)$ & \\
\hline Case 1 & P90 & México & 0.3 & M & Low weight & ANC $100-800 / \mu 1$ & lgG 398 mg/dl & Hypocellu \\
\hline (this report) & & & & & $\begin{array}{l}\text { Persistent foramen } \\
\text { ovale }\end{array}$ & $\begin{array}{l}\text { Intermittent } \\
\text { thrombocytopenia }\end{array}$ & $(290-550)$ & myeloid d \\
\hline & & & & & & (1400 140 & $\operatorname{lgM} 114 \mathrm{mg} / \mathrm{dl}$ & \\
\hline & & & & & $\mathrm{PH}$ & ALC $1400 / \mu \mathrm{l}$ & $(30-85)$ & \\
\hline
\end{tabular}

Page 18/25 


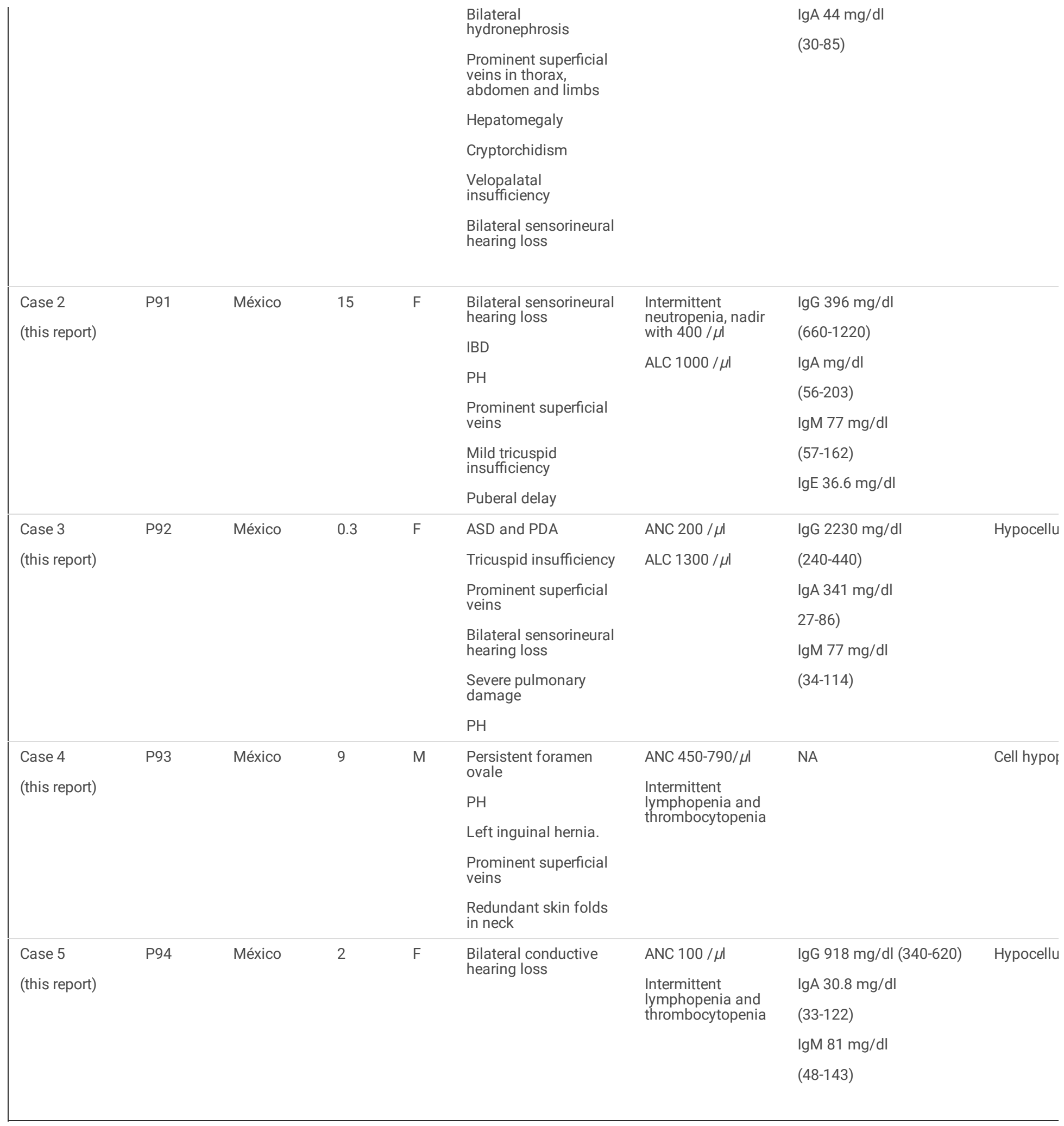

a. Age at diagnosis or follow up

b. F, female; M, male, NA, not available

ASD, atrial septal defect; $\mathrm{Hb}$, hemoglobin; ANC, absolute neutrophil count; ALC, absolute lymphocyte count; Ig, immunoglobulin; G-CSF, granulocyte colonystimulating factor; PDA, persistent ductus arteriosus; HSCT, hematopoietic stem cell transplantation; PH, pulmonary hypertension; IVIG intravenous gammaglobulin; TMP-SMX, trimethoprim sulfamethoxazole; NB, newborn; IBD, inflammatory bowel disease

Table 2. Genetic information of 94 G6PC3 deficient patients 


\begin{tabular}{|c|c|c|c|c|c|c|}
\hline Author & Individual & $\begin{array}{l}\text { Country or } \\
\text { ethnicity }\end{array}$ & Genotype & Protein change & Variant type & Syndromic \\
\hline $\begin{array}{l}\text { Boztug, } \\
2009\end{array}$ & P1 & Turkey & c. $[758 \mathrm{G}>\mathrm{A}]$ & p.[Arg253His] & Missense, homozygous & Yes \\
\hline $\begin{array}{l}\text { Boztug, } \\
2009\end{array}$ & P2 & Turkey & c. $[758 \mathrm{G}>\mathrm{A}]$ & p.[Arg253His] & Missense, homozygous & Yes \\
\hline $\begin{array}{l}\text { Boztug, } \\
2009\end{array}$ & P3 & Turkey & c. $[758 \mathrm{G}>\mathrm{A}]$ & p.[Arg253His] & Missense, homozygous & Yes \\
\hline $\begin{array}{l}\text { Boztug, } \\
2009\end{array}$ & P4 & Turkey & c. $[758 \mathrm{G}>\mathrm{A}]$ & p.[Arg253His] & Missense, homozygous & Yes \\
\hline $\begin{array}{l}\text { Boztug, } \\
2009\end{array}$ & P5 & Turkey & c. $[758 \mathrm{G}>\mathrm{A}]$ & p.[Arg253His] & Missense, homozygous & Yes \\
\hline $\begin{array}{l}\text { Boztug, } \\
2009\end{array}$ & P6 & Turkey & c. $[554 \mathrm{TT}>\mathrm{C}]$ & p. [Leu185Pro] & Missense, homozygous & Yes \\
\hline $\begin{array}{l}\text { Boztug, } \\
2009\end{array}$ & P7 & Greece & c. $[141 \mathrm{C}>\mathrm{G}]$ & p. [Tyr47Ter] & Nonsense, homozygous & Yes \\
\hline $\begin{array}{l}\text { Boztug, } \\
2009\end{array}$ & P8 & Germany & c. $[784 \mathrm{G}>\mathrm{C}]$ & p.[Gly260Arg] & Missense, homozygous & Yes \\
\hline $\begin{array}{l}\text { Boztug, } \\
2009\end{array}$ & P9 & France & $\begin{array}{l}\text { c. }[677+1 \mathrm{G}>\mathrm{A}]+ \\
{[829 \mathrm{C}>\mathrm{T}]}\end{array}$ & p. [?] + [GIn277Ter] & Nonsense, comp.het? & Yes \\
\hline $\begin{array}{l}\text { Boztug, } \\
2009\end{array}$ & $\mathrm{P} 10$ & Germany & c. $[778 \mathrm{G}>C]$ & p. [Gly260Arg] & Missense, homozygous & Yes \\
\hline $\begin{array}{l}\text { Boztug, } \\
2009\end{array}$ & P11 & Iran & c. [935dupT] & p. [Asn313fs] & Frameshift, homozygous & No \\
\hline $\begin{array}{l}\text { Boztug, } \\
2009\end{array}$ & $\mathrm{P} 12$ & Lebanese & c. $[144 \mathrm{C}>\mathrm{A}]$ & p. [Tyr48Ter] & Nonsense, homozygous & Yes \\
\hline $\begin{array}{l}\text { Eghbali, } \\
2009\end{array}$ & P13 & Iran & c. $\left[935 \_936 \mathrm{ins} T\right]$ & p.[Asn313fs] & Insertion/Frameshift, homoz. & Yes \\
\hline $\begin{array}{l}\text { Dursun, } \\
2009\end{array}$ & P14 & Turkish & c. $[346 \mathrm{~A}>\mathrm{C}]$ & p.[Met116Val] & Missense, homozygous & Yes \\
\hline $\begin{array}{l}\text { Dursun, } \\
2009\end{array}$ & P15 & Turkish & c. $[346 \mathrm{~A}>C]$ & p.[Met116Val] & Missense, homozygous & Yes \\
\hline $\begin{array}{l}\text { Arostegui, } \\
2009\end{array}$ & P16 & Moroccan & c.[257delA] & p.[Glu86fs] & Frameshift, homozygous & Yes \\
\hline $\begin{array}{l}\text { Xia, } \\
2009\end{array}$ & P17 & USA & NR & NR & NR & No \\
\hline $\begin{array}{l}\text { Xia, } \\
2009\end{array}$ & P18 & USA & c.[210delC] & p.[170fsTer46] & Frameshift, homozygous & No \\
\hline $\begin{array}{l}\text { McDermott, } \\
2010\end{array}$ & P19 & $\begin{array}{l}\text { USA } \\
\text { (Caucasian) }\end{array}$ & c. $[778 \mathrm{G}>\mathrm{C}]$ & p. [Gly260Arg] & Missense, homozygous & Yes \\
\hline $\begin{array}{l}\text { McDermott, } \\
2010\end{array}$ & $\mathrm{P} 20$ & $\begin{array}{l}\text { USA } \\
\text { (Caucasian) }\end{array}$ & c. $[778 \mathrm{G}>\mathrm{C}]$ & p. [Gly260Arg] & Missense, homozygous & Yes \\
\hline $\begin{array}{l}\text { Germeshausen, } \\
2010\end{array}$ & P21 & Turkish & c. $[347 \mathrm{~T}>\mathrm{A}]$ & p. Met116Lys & Missense, homozygous & Yes \\
\hline
\end{tabular}




\begin{tabular}{|c|c|c|c|c|c|c|}
\hline $\begin{array}{l}\text { Germeshausen, } \\
2010\end{array}$ & $\mathrm{P} 22$ & Caucasian & c. $[778 \mathrm{G}>\mathrm{C}]$ & p.[Gly260Arg] & Missense, homozygous & Yes \\
\hline $\begin{array}{l}\text { Germeshausen, } \\
2010\end{array}$ & $\mathrm{P} 23$ & Caucasian & NR & p.[Arg189GIn] & Missense, homozygous & No \\
\hline $\begin{array}{l}\text { Hayee, } \\
2011\end{array}$ & P24 & Pakistan & c. $[130 \mathrm{C}>\mathrm{T}]$ & p.[Pro44Ser] & Missense, homozygous & No \\
\hline $\begin{array}{l}\text { Hayee, } \\
2011\end{array}$ & P25 & Pakistan & c.[190_210del] & p. [Thr64_lle70del] & Small deletion, homozygous & Yes \\
\hline $\begin{array}{l}\text { Gatti, } \\
2011\end{array}$ & P26 & Ecuador & c. [765_delAG] & p.[Ser255fs] & Small del/Frameshift, homoz. & Yes \\
\hline $\begin{array}{l}\text { Cullinane, } \\
2011\end{array}$ & $\mathrm{P} 27$ & $\begin{array}{l}\text { USA } \\
\text { (Caucasian) }\end{array}$ & c.[986delC] & p.[Thr329ArgfsTer68] & SN del/Frameshift, homoz. & Yes \\
\hline $\begin{array}{l}\text { Banka, } \\
2011\end{array}$ & P28 & Israel & c. $[758 \mathrm{G}>\mathrm{A}]$ & p.[Arg253His] & Missense, homoz. & Yes \\
\hline $\begin{array}{l}\text { Banka, } \\
2011\end{array}$ & P29 & Israel & c. $[758 \mathrm{G}>\mathrm{A}]$ & p.[Arg253His] & Missense, homoz. & Yes \\
\hline $\begin{array}{l}\text { Banka, } \\
2011\end{array}$ & P30 & Israel & c. $[758 \mathrm{G}>\mathrm{A}]$ & p.[Arg253His] & Missense, homoz. & Yes \\
\hline $\begin{array}{l}\text { Banka, } \\
2011\end{array}$ & P31 & Israel & c. $[758 \mathrm{G}>\mathrm{A}]$ & p.[Arg253His] & Missense, homoz. & Yes \\
\hline $\begin{array}{l}\text { Alizadeh, } \\
2011\end{array}$ & P32 & Persian & c. $[416 \mathrm{G}>\mathrm{T}]$ & NR & NR & No \\
\hline $\begin{array}{l}\text { Alizadeh, } \\
2011\end{array}$ & P33 & Persian & c. [935dupT] & p.[Asn313fs] & Dup/Frameshift, homoz. & Yes \\
\hline $\begin{array}{l}\text { Fernandez, } \\
2012\end{array}$ & P34 & Canada & c. $[829 \mathrm{C}>\mathrm{T}]$ & p.[GIn277Ter] & Nonsense, homozygous & Yes \\
\hline $\begin{array}{l}\text { Smith, } \\
2012\end{array}$ & P35 & Pakistan & c.[190_210del] & p.[Thr64_lle70del] & In-frame 21 bp deletion, homoz. & Yes \\
\hline $\begin{array}{l}\text { Smith, } \\
2012\end{array}$ & P36 & Turkey & c. $[623 \mathrm{~T}>\mathrm{G}]$ & p.[Leu208Arg] & Missense, homozygous & No \\
\hline $\begin{array}{l}\text { Smith, } \\
2012\end{array}$ & P37 & Pakistan & c. $[130 \mathrm{C}>\mathrm{T}]$ & p. [Pro44Ser] & Missense, homozygous & No \\
\hline $\begin{array}{l}\text { Smith, } \\
2012\end{array}$ & P38 & Pakistan & c. $[130 \mathrm{C}>\mathrm{T}]$ & p. [Pro44Ser] & Missense, homozygous & No \\
\hline $\begin{array}{l}\text { Boztug, } \\
2012\end{array}$ & P39 & Arab & c. $[758 \mathrm{G}>\mathrm{A}]$ & p.[Arg253His] & Missense, homozygous & Yes \\
\hline $\begin{array}{l}\text { Boztug, } \\
2012\end{array}$ & P40 & Hispanic & c. $[218+1 \mathrm{G}>\mathrm{A}]$ & NR & Splice-site intronic, homoz. & Yes \\
\hline $\begin{array}{l}\text { Boztug, } \\
2012\end{array}$ & P41 & Caucasian & c. $[758 \mathrm{G}>\mathrm{C}]$ & p.[Gly260Arg] & Missense, homoz. & Yes \\
\hline $\begin{array}{l}\text { Boztug, } \\
2012\end{array}$ & P42 & Caucasian & c. $[758 \mathrm{G}>\mathrm{C}]$ & p p.[Gly260Arg] & Missense , homoz. & Yes \\
\hline $\begin{array}{l}\text { Boztug, } \\
2012\end{array}$ & P43 & Caucasian & $\begin{array}{l}\text { c. }[208 \text { insC }]+ \\
{[778 \mathrm{G}>\mathrm{C}]}\end{array}$ & p.[Ile70fsTer16]+[Gly260Arg] & $\begin{array}{l}\text { SN insertion/frameshift + } \\
\text { Missense (comp.het) }\end{array}$ & Yes \\
\hline Boztug, & P44 & Hispanic & c.[766_777delAG] & p.[Ser255fs] & Frameshift, homozygous & Yes \\
\hline
\end{tabular}

Page 21/ 25 


\begin{tabular}{|c|c|c|c|c|c|c|}
\hline $\begin{array}{l}\text { Boztug, } \\
2012\end{array}$ & P45 & Hispanic & $\begin{array}{l}\text { c. }[210 \mathrm{delC}]+ \\
{[348 \mathrm{G}>\mathrm{A}]}\end{array}$ & p.[Ile70fsTer46] + [Met116lle] & Frameshift, homozygous & Yes \\
\hline $\begin{array}{l}\text { Boztug, } \\
2012\end{array}$ & P46 & Caucasian & $\begin{array}{l}\text { c. }[677+1 \mathrm{G}>\mathrm{A}]+ \\
{[829>\mathrm{T}]}\end{array}$ & p.[?]+[GIn277Ter] & $\begin{array}{l}\text { Splice-site intronic + Nonsense, } \\
\text { (Comp.het) }\end{array}$ & Yes \\
\hline $\begin{array}{l}\text { Boztug, } \\
2012\end{array}$ & P47 & Persian & c.[935dupT] & p. [Asn313fs] & SN dup/Frameshift, homoz. & Yes \\
\hline $\begin{array}{l}\text { Boztug, } \\
2012\end{array}$ & P48 & Hispanic & c.[210delC] & p.[Phe71fsTer45] & SN del/Frameshift, homoz. & Yes \\
\hline $\begin{array}{l}\text { Boztug, } \\
2012\end{array}$ & P49 & Hispanic & c. [210delC] & p. [lle70fsTer4] & SN del/Frameshift, homoz. & Yes \\
\hline $\begin{array}{l}\text { Boztug, } \\
2012\end{array}$ & P50 & Turkish & c. $[779 \mathrm{G}>A]$ & p.[Gly260Asp] & Missense, homoz. & Yes \\
\hline $\begin{array}{l}\text { Boztug, } \\
2012\end{array}$ & P51 & Persian & c. $[416 \mathrm{G}>\mathrm{T}]$ & p. [Ser139lle] & Missense, homoz. & Yes \\
\hline $\begin{array}{l}\text { Boztug, } \\
2012\end{array}$ & P52 & Caucasian & $\begin{array}{l}\text { c. }[482 \mathrm{G}>\mathrm{A}]+ \\
{[565 \mathrm{C}>\mathrm{T}]}\end{array}$ & p. $[\operatorname{Arg} 161 \mathrm{Gln}]+[\operatorname{Arg} 189 \mathrm{Ter}]$ & Missense + Nonsense, comp.het. & Yes \\
\hline $\begin{array}{l}\text { Boztug, } \\
2012\end{array}$ & P53 & Pakistani & c. [766_777delAG] & p. [Ser255fs] & Small del./Frameshift, homoz. & Yes \\
\hline $\begin{array}{l}\text { Boztug, } \\
2012\end{array}$ & P54 & $\begin{array}{l}\text { White } \\
\text { caucasian }\end{array}$ & $\begin{array}{l}\text { c. }[131 C>T]+[758 \\
G>A]\end{array}$ & p. [Pro44Leu]+[Arg253His] & Missense, comp.het. & Yes \\
\hline $\begin{array}{l}\text { Aytekin, } \\
2013\end{array}$ & P55 & Turkey & c. $[461 \mathrm{~T}>\mathrm{C}]$ & p.[Leu154Pro] & Missense, homozygous & Yes \\
\hline $\begin{array}{l}\text { Banka, } \\
2013\end{array}$ & P56 & Pakistan & $c .[130 c>T]$ & p.[Pro44Ser] & Missense, homozygous & No \\
\hline $\begin{array}{l}\text { Banka, } \\
2013\end{array}$ & P57 & Pakistan & c. $[347 \mathrm{~T}>\mathrm{C}]$ & p.[Met116Thr] & Missense, homozygous & No \\
\hline $\begin{array}{l}\text { Banka, } \\
2013\end{array}$ & P58 & $\begin{array}{l}\text { Great } \\
\text { Britain }\end{array}$ & $\begin{array}{l}\text { c. }[757 C>T]+ \\
{\left[1000 \_1001\right]}\end{array}$ & p. $[$ Arg253Cys $]+[$ Met334fs $]$ & $\begin{array}{l}\text { Missense + Small del/Frameshift, } \\
\text { comp.het. }\end{array}$ & No \\
\hline $\begin{array}{l}\text { Banka, } \\
2013\end{array}$ & P59 & $\begin{array}{l}\text { Great } \\
\text { Britain }\end{array}$ & $\begin{array}{l}\text { c. }[757 C>T]+ \\
{\left[1000 \_1001\right]}\end{array}$ & p. $[$ Arg253Cys $]+[$ Met334fs $]$ & $\begin{array}{l}\text { Missense + Small del/Frameshift, } \\
\text { comp.het. }\end{array}$ & No \\
\hline $\begin{array}{l}\text { Bégin, } \\
2013\end{array}$ & P60 & Canada & $\begin{array}{l}\text { c. [IVS3-1 G>A]+ } \\
{[\mathrm{G} 778 \mathrm{G}>\mathrm{C}]}\end{array}$ & p.[?] + [Gly260Arg] & $\begin{array}{l}\text { Splice-site intronic + Missense, } \\
\text { comp.het. }\end{array}$ & Yes \\
\hline $\begin{array}{l}\text { Estévez, } \\
2013\end{array}$ & P61 & Caucasian & c. $[778 \mathrm{G}>\mathrm{C}]$ & p.[Gly260Arg] & Missense, homozygous & Yes \\
\hline $\begin{array}{l}\text { Alangeri, } \\
2013\end{array}$ & P62 & $\begin{array}{l}\text { Saudi } \\
\text { Arabia }\end{array}$ & c. $[974 \mathrm{~T}>\mathrm{G}]$ & p.[Leu325Arg] & Missense, homozygous & No \\
\hline $\begin{array}{l}\text { Alangeri, } \\
2013\end{array}$ & P63 & $\begin{array}{l}\text { Saudi } \\
\text { Arabia }\end{array}$ & c. $[974 \mathrm{~T}>\mathrm{G}]$ & p.[Leu325Arg] & Missense, homozygous & No \\
\hline $\begin{array}{l}\text { Alangeri, } \\
2013\end{array}$ & P64 & $\begin{array}{l}\text { Saudi } \\
\text { Arabia }\end{array}$ & c. $[974 \mathrm{~T}>\mathrm{G}]$ & p.[Leu325Arg] & Missense, homozygous & No \\
\hline $\begin{array}{l}\text { Alangeri, } \\
2013\end{array}$ & P65 & $\begin{array}{l}\text { Saudi } \\
\text { Arabia }\end{array}$ & c. $[974 \mathrm{~T}>\mathrm{G}]$ & p.[Leu325Arg] & Missense, homozygous & No \\
\hline Alangeri, & P66 & Saudi & c. $[974 \mathrm{~T}>\mathrm{G}]$ & p.[Leu325Arg] & Missense, homozygous & No \\
\hline
\end{tabular}

Page 22/25 


\begin{tabular}{|c|c|c|c|c|c|c|}
\hline 2013 & & Arabia & & & & \\
\hline $\begin{array}{l}\text { Arikoglu, } \\
2014\end{array}$ & P67 & Turkey & c. $[175 \mathrm{~T}>\mathrm{C}]$ & p.[Trp59Arg] & Missense, homozygous & Yes \\
\hline $\begin{array}{l}\text { Kaya, } \\
2014\end{array}$ & P68 & Turkey & c. $[623 T>C]$ & p.[Leu208Arg] & Missense, homozygous & No \\
\hline $\begin{array}{l}\text { Kaya, } \\
2014\end{array}$ & P69 & Turkey & NR & NR & NR & No \\
\hline $\begin{array}{l}\text { Desplantes, } \\
2014\end{array}$ & P70 & France & c. $[249 \mathrm{G}>\mathrm{A}]$ & p.[Trp83Ter] & Nonsense, homozygous & Yes \\
\hline $\begin{array}{l}\text { Desplantes, } \\
2014\end{array}$ & P71 & France & c. $[249 \mathrm{G}>\mathrm{A}]$ & p.[Trp83Ter] & Nonsense, homozygous & Yes \\
\hline $\begin{array}{l}\text { Desplantes, } \\
2014\end{array}$ & P72 & France & c. $[249 \mathrm{G}>\mathrm{A}]$ & p.[Trp83Ter] & Nonsense, homozygous & Yes \\
\hline $\begin{array}{l}\text { Desplantes, } \\
2014\end{array}$ & P73 & France & c. $[249 \mathrm{G}>\mathrm{A}]$ & p.[Trp83Ter] & Nonsense, homozygous & Yes \\
\hline $\begin{array}{l}\text { Desplantes, } \\
2014\end{array}$ & P74 & France & c. $[249 \mathrm{G}>\mathrm{A}]$ & p.[Trp83Ter] & Nonsense, homozygous & Yes \\
\hline $\begin{array}{l}\text { Desplantes, } \\
2014\end{array}$ & P75 & France & c. $[758 \mathrm{G}>\mathrm{A}]$ & p.[Arg253His] & Missense, homozygous & Yes \\
\hline $\begin{array}{l}\text { Desplantes, } \\
2014\end{array}$ & P76 & France & c. $[481 \mathrm{C}>\mathrm{T}]$ & p.[Arg161Ter] & Nonsense, homozygous & yes \\
\hline $\begin{array}{l}\text { Desplantes, } \\
2014\end{array}$ & P77 & France & c. $[778 \mathrm{G}>\mathrm{C}]$ & p.[Gly260Arg] & Missense, homozygous & Yes \\
\hline $\begin{array}{l}\text { Desplantes, } \\
2014\end{array}$ & P78 & France & c. $[778 \mathrm{G}>\mathrm{C}]$ & p.[Gly260Arg] & Missense, homozygous & Yes \\
\hline $\begin{array}{l}\text { Desplantes, } \\
2014\end{array}$ & P79 & France & c. $[778 \mathrm{G}>\mathrm{C}]$ & p.[Gly260Arg] & Missense, homozygous & No \\
\hline $\begin{array}{l}\text { Desplantes, } \\
2014\end{array}$ & P80 & France & c. $[565 \mathrm{C}>\mathrm{T}]$ & p.[Arg189Ter] & Nonsense, homozygous & Yes \\
\hline $\begin{array}{l}\text { Desplantes, } \\
2014\end{array}$ & P81 & France & c. $[565 \mathrm{C}>\mathrm{T}]$ & p.[Arg189Ter] & Nonsense, homozygous & Yes \\
\hline $\begin{array}{l}\text { Desplantes, } \\
2014\end{array}$ & P82 & France & c. $[565 \mathrm{C}>\mathrm{T}]$ & p.[Arg189Ter] & Nonsense, homozygous & Yes \\
\hline $\begin{array}{l}\text { Notarangelo, } \\
2014\end{array}$ & P83 & Italy & $\begin{array}{l}\text { c.[144C>A]+ } \\
{\left[373 \_375 d e l A A T\right]}\end{array}$ & p.[Tyr48Ter]+[Ile125del] & $\begin{array}{l}\text { Nonsense + In-frame del, } \\
\text { comp.het. }\end{array}$ & Yes \\
\hline $\begin{array}{l}\text { Notarangelo, } \\
2014\end{array}$ & P84 & Turkey & c.[680_684delinsT] & p.[Ser227LeufsTer3] & Indel/Frameshift, homozygous & Yes \\
\hline $\begin{array}{l}\text { Kiykim, } \\
2015\end{array}$ & P85 & Turkey & c. $[535+1 G>A]$ & NR & Splicesite intronic, homozygous & Yes \\
\hline $\begin{array}{l}\text { Kiykim, } \\
2015\end{array}$ & P86 & Turkey & c. [935dupT] & p. [Asn313fs] & SN dup/frameshift, homoz. & Yes \\
\hline $\begin{array}{l}\text { Kiykim, } \\
2015\end{array}$ & P87 & Turkey & c. [C394T] & p.[Glu132Ter] & Nonsense, homozygous & Yes \\
\hline $\begin{array}{l}\text { Mistry, } \\
2017\end{array}$ & P88 & $\begin{array}{l}\text { Great } \\
\text { Britain }\end{array}$ & c. $[130 \mathrm{C}>\mathrm{T}]$ & p.[Pro44Ser] & Missense, homozygous & Yes \\
\hline
\end{tabular}




\begin{tabular}{|c|c|c|c|c|c|c|}
\hline $\begin{array}{l}\text { Bolton, } \\
2019\end{array}$ & P89 & $\begin{array}{l}\text { Great } \\
\text { Britain }\end{array}$ & c.[911dupC] & p.[Gln305fs82Ter] & SN dup/frameshift, homozygous & No \\
\hline C1 (this report) & P90 & México & c.[210delC] & p.[Phe71SerfsTer46] & SN deletion/frameshift, homoz. & Yes \\
\hline C2 (this report) & P91 & México & c.[210delC] & p.[Phe71SerfsTer46] & SN deletion/frameshift, homoz. & Yes \\
\hline C3 (this report) & P92 & México & c.[210delC] & p.[Phe71SerfsTer46] & SN deletion/frameshift, homoz. & Yes \\
\hline C4 (this report) & P93 & México & $\begin{array}{l}\text { c. }[210 \mathrm{del}]+\mathrm{c} . \\
{[481 \mathrm{C}>\mathrm{T}]}\end{array}$ & $\begin{array}{l}\text { p.[Phe71SerfsTer46] + } \\
\text { Arg161Ter] }\end{array}$ & $\begin{array}{l}\text { SN deletion/frameshift + } \\
\text { Nonsense (comp.het) }\end{array}$ & Yes \\
\hline C5 (this report) & P94 & México & c.[210del] + [421del] & $\begin{array}{l}\text { p.[Phe71SerfsTer46] + } \\
\text { Trp141GlyfsTer2] }\end{array}$ & SN deletion/frameshift, comp.het. & No \\
\hline
\end{tabular}

NR, not reported.

Due to technical limitations, table 3 is only available as a download in the Supplemental Files section.

\section{Figures}
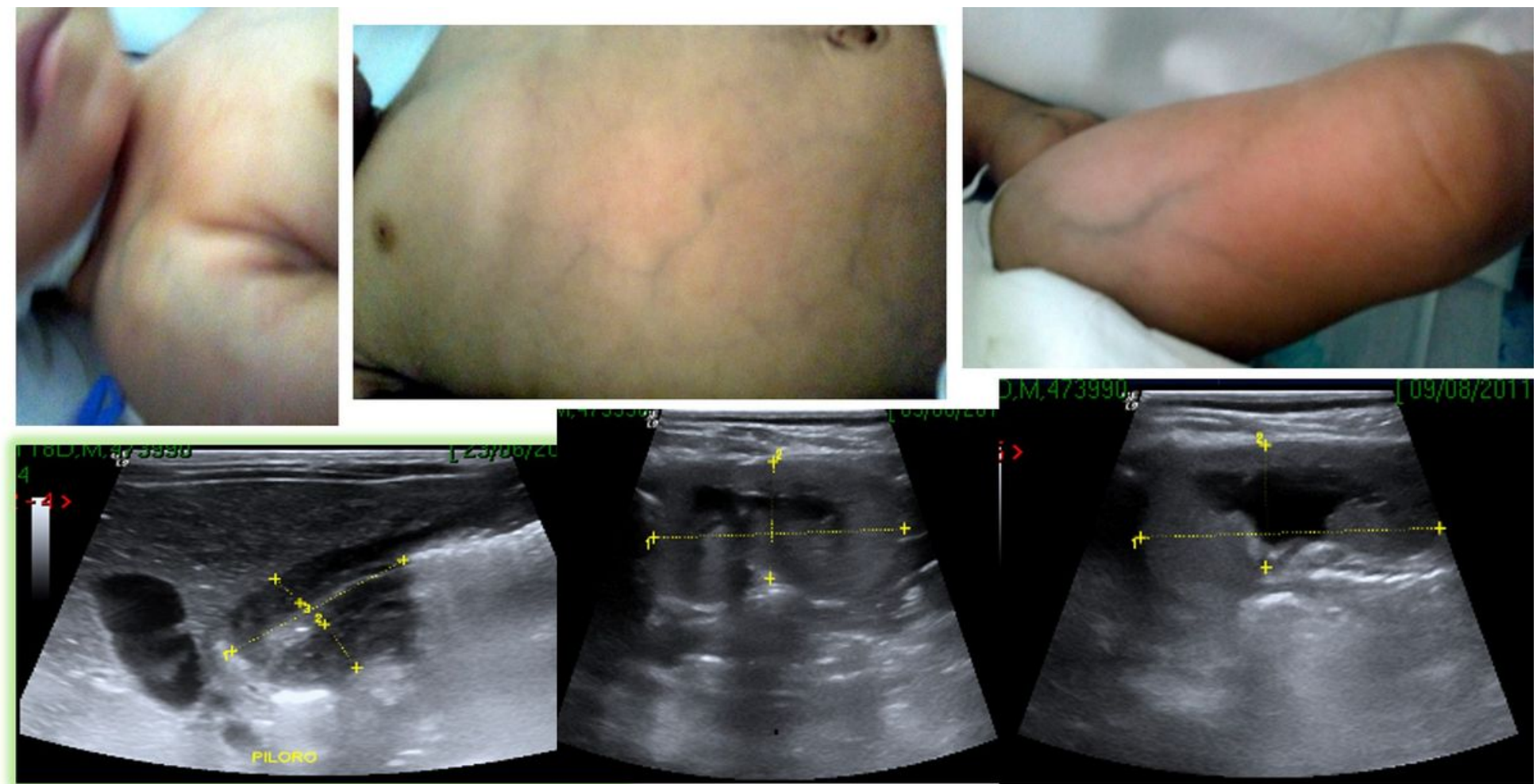

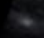
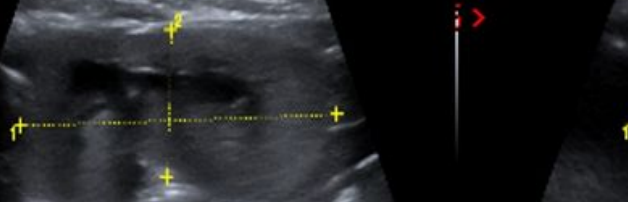

$+$

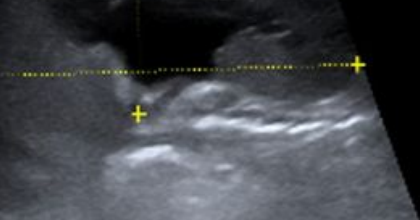

\section{Figure 1}

Patient 1 had prominent superficial veins in trunk and limbs (upper panels), pyloric hypertrophy and severe bilateral hydronephrosis grade I and III (lower panels), as well as persistent foramen ovale with bidirectional shunt and pulmonary arterial hypertension, hepatomegaly, cryptorchidia, and bilateral hypoacusis (not shown). 

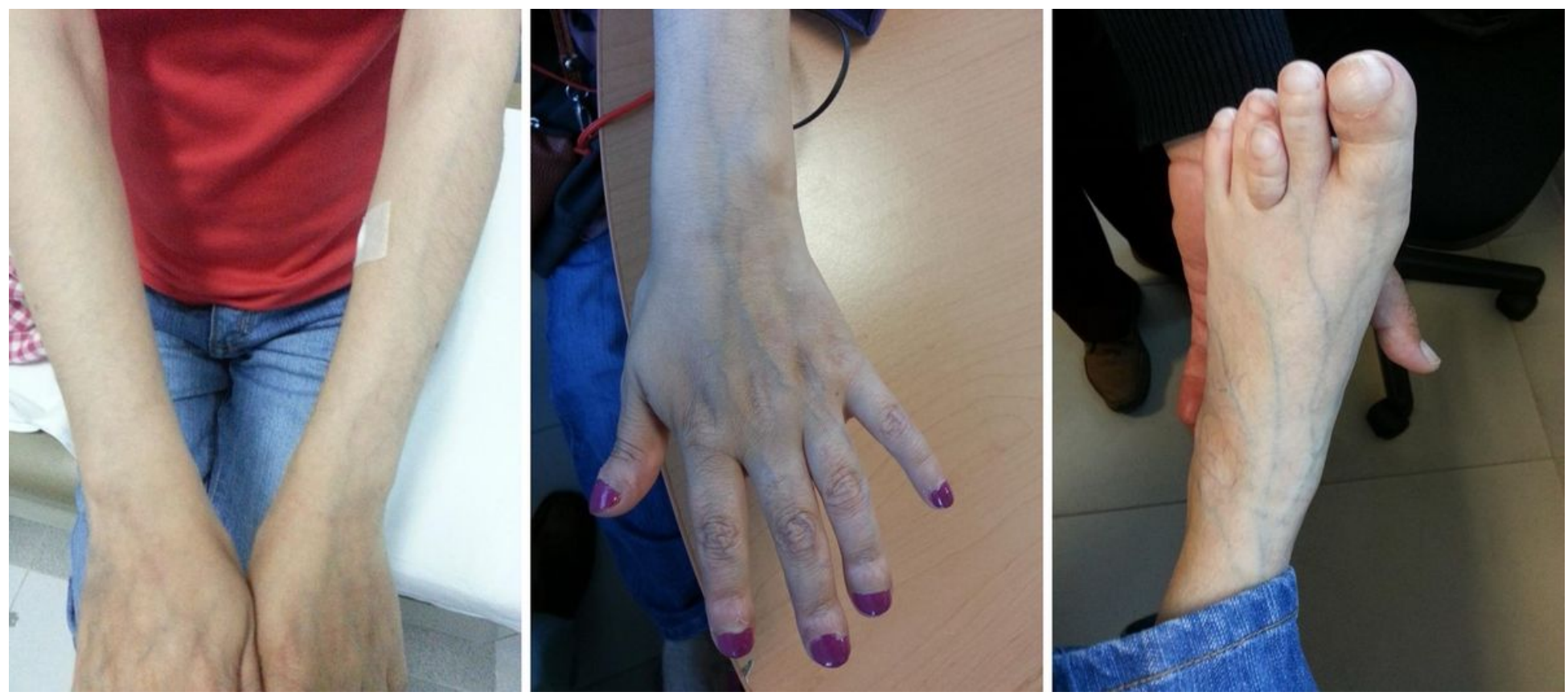

\section{Figure 2}

Patient 2 also had prominent superficial veins in limbs, digital clubbing, brachymetatarsia of the third toe, and bilateral hypoacusis.

\section{Supplementary Files}

This is a list of supplementary files associated with this preprint. Click to download.

- Table3.jpg

- G6PC3tablefinal1.docx 